CENTRE FOR ECONOMIC PERFORMANCE

DISCUSSION PAPER NO. 272

December 1995

POLITICS AND THE EFFECTIVENESS OF FOREIGN AID

P. BOONE 


\section{ABSTRACT}

Critics of foreign aid programs have long argued that poverty reflects government failure. In this paper I analyze the effectiveness of foreign aid programs to gain insights into political regimes in aid recipient countries. My analytical framework shows how three stylized political/economic regimes labeled egalitarian, elitist and laissez-faire would use foreign aid. I then test reduced form equations using data on nonmilitary aid flows to 96 countries. I find that models of elitist political regimes best predict the impact of foreign aid. Aid does not significantly increase investment and growth, nor benefit the poor as measured by improvements in human development indicators, but it does increase the size of government. I also find that the impact of aid does not vary according to whether recipient governments are liberal democratic or highly repressive. But liberal political regimes and democracies, ceteris paribus, have on average 30\% lower infant mortality than the least free regimes. This may be due to greater empowerment of the poor under liberal regimes even though the political elite continues to receive the benefits of aid programs. An implication is that short term aid targeted to support new liberal regimes may be a more successful means of reducing poverty than current programs.

This paper was produced as part of the Centre's

Programme on Post Communist Reform

\section{POLITICS AND THE EFFECTIVENESS OF FOREIGN AID}


Peter Boone

DECEMBER 1995 
Published by

Centre for Economic Performance

London School of Economics and Political Science

Houghton Street

London WC2A 2AE

๑P. Boone

ISBN 0753003252 


\section{POLITICS AND THE EFFECTIVENESS OF FOREIGN AID}

\section{Peter Boone}

Page

1. Introduction 1

2. Public Choice Under alternative Political Regimes

3. Empirical Test 13

4. Data Sources and Definitions 15

5. The Motives for Giving Aid 17

6. Instruments and Econometric Implementation 19

7. The Aggregate Impact of Aid Flows 21

8. Do Alternative Political Regimes Use Aid Differently?

9. Conclusions

Endnotes $\quad 30$

Appendices $\quad 36$

Tables $\quad 42$

Figures $\quad 50$

References $\quad 54$

Peter Boone is a Dr of Economics at the London School of Economics and Director of the Post Communist Reform programme at the Centre for Economic Performance. The Centre for Economic Performance is financed by the Economic and Social Research Council. 


\section{ACKNOWLEDGEMENTS}

I'm grateful for comments from Robert Barro, Charlie Bean, William Easterly, Barry Eichengreen, Danny Quah, Sweder van Wijnbergen, and Eric Van Wincoop for helpful comments and seminar participants at the International Monetary Fund, ISOM, the LSE Macroeconomics workshop, the NBER growth conference at the Universitat Pompeu Fabra, the London School of Hygiene and Tropical Medicine, University of Miami, University of Reading and the World Bank. The data on foreign aid used in this paper was provided by the Development Assistance Committee at the Organization for Economic Cooperation and Development for the purpose of academic research. 


\title{
POLITICS AND THE EFFECTIVENESS OF FOREIGN AID
}

\author{
Peter Boone
}

\section{Introduction}

Foreign aid programs were launched long before there was compelling theory, or compelling evidence that proved they could work. The stated goal of these programs was to alleviate poverty and promote growth. The massive aid programs that began after the second world war, but only took off in the 1960s, are an unprecedented economic experiment. Donors transferred approximately $\$ 50$ billion of nonmilitary aid in 1991 to developing countries, averaging over 8\% of the recipient country's GNP in 1981-90. These transfers are highly variable (see Figure 1 and Table 1), fungible, and to a large extent politically motivated. The impact of aid can be used as an interesting test of alternative theories of development. Aid can also teach us about political regimes in recipient countries. In this paper I focus on what can be learned about political systems.

There are several possible channels by which aid could alleviate poverty. The early literature focused on capital market imperfections. If capital is not mobile, poor countries may have a set of profitable investment projects that are not undertaken due to a shortage of domestic savings. Low savings may be due to absolute poverty when people have minimum subsistence needs. But a more careful examination makes this explanation seem implausible. Capital markets do function - during the last twenty years we have seen extremely large net capital flows to developing countries. Further, the richest $20 \%$ of the population earn more than $50 \%$ of income in developing countries. ${ }^{1}$ We might instead ask the question: Why does the high income elite choose to invest domestically in some countries while in others they don't?

A second mechanism by which aid leads to growth is through fiscal policy. Barro (1990) presents an endogenous growth model where a benevolent dictator uses distortionary taxation to finance productive public expenditures. The planner chooses the optimal tax rate by comparing the social costs of higher taxation to the benefits of more public goods. Barro's model predicts that foreign assistance causes 
faster growth and higher investment since the social planner can reduce distortionary taxes.

But this mechanism depends critically on the political regime. The most ardent critics of aid programs, especially PT Bauer (1971) and Milton Friedman (1958), attack foreign assistance on the grounds that politicians will not allocate aid efficiently when measured against the goals of aid programs. They argue that recipient countries will consume capital inflows since lack of domestic savings reflects lack of opportunities. The political elite will benefit from aid flows. ${ }^{2}$

This paper analyzes the importance of the political regime for the effectiveness of aid programs. Standard categorizations of political regimes do not correlate with clear economic regimes. A simple contrast of leaders in East Asia shows that authoritarian regimes/dictatorships can be quasi-benevolent such as President Lee of Singapore, or highly rent seeking such as President Marcos. Bayart (1994) lists 10 African dictators whom he claims used public office to divert large sums, including foreign aid, to their tribe members or clients. ${ }^{3}$ And elected or authoritarian populist regimes, defined as regimes "seeking to mobilize and represent the poor", 4 also use distortionary policies to redirect funds to their supporters.

In order to relate political regimes to economic systems, I begin by categorizing alternative political regimes in terms of the interest groups they support. My approach is motivated by a series of papers by Becker (1983, 1985a, 1985b, 1989). Becker (1983) presents a public choice model where a government chooses tax and spending policies as an outcome of strategic interaction between groups that are endowed with different political "influence". Influence is exogenously endowed to citizens. He argues that in all political regimes each citizen's relative influence will vary both for institutional and other reasons. Democracies may allocate influence more evenly across the population, but even so people's ability to mobilize support and influence government will still depend on other attributes such as education, health, skills and the ability to form coalitions.

In my framework ruling politicians maximize welfare over a weighted sum of citizen's utilities. Politicians use distortionary taxation and foreign aid to finance productive government spending and transfers 
to their political supporters. I contrast how foreign aid is used under three extreme, alternative political regimes that fall out naturally from this framework. An Elitist government maximizes the welfare of a fixed ruling coalition. Its optimal policy is to transfer foreign aid to a high income political elite. An Egalitarian government maximizes the welfare of a fixed group of citizens with relatively low endowments. Its optimal policy is to transfer foreign aid to households with low initial endowments. This should improve poverty indicators. A Laissez-Faire government maximizes the welfare of a minimum (and substantial) fraction of the population. Its optimal policy is to use aid to lower distortionary taxes. This leads to higher investment and income. Only the elitist political regime wastes foreign aid as described by Bauer and Friedman.

I then test the reduced form equations from this model using data on nonmilitary foreign aid transfers, national accounts, human development indicators, and indexes of political liberties and political regimes from 97 countries. I use three alternative instruments, conduct instrument specification tests, and examine robustness using alternative subsamples and regression techniques. The previous literature on the empirical impact of foreign aid is surprisingly limited. This may be due to the difficulty in finding suitable instruments. Mosley et al (1986) are the closest in spirit to this paper. Using cross country regressions they conclude that aid does not raise growth rates. Papanek (1972) strongly criticizes an early literature on the impact of foreign aid. He describes a range of potential problems due to simultaneity and measurement error. I will discuss relevant papers in the sections that follow, but other general papers on aid include Chenery and Ecksteing (1970), Chenery and Syrquin (1975), Griffin (1970), Levy (1987), Levy (1988), Papanek (1973), Weisskopf (1972) and Boone (1995).

My empirical results suggest that elitist regimes best predict the impact of aid. The marginal propensity to consume from aid is insignificantly different from one, and the marginal propensity to invest is insignificantly different from zero. There is one important caveat to these findings. In small countries, or countries where the aid/GNP ratio is extremely large (over 15\% of GNP) I find that aid does lead to higher investment. This is probably due to the lack of fungibility of aid flows 
in such countries. In a small country one dam or large public infrastructure project can represent a sizable portion of GNP, and the project is unlikely to be fungible. But in other work not repeated here, Boone (1995), and consistent with Mosley et al (1986), I found that in all countries there was no significant correlation between aid and growth. This empirical evidence implies capital shortage is not the primary cause of poverty in aid recipient countries. I find no significant impact of aid on tax proxies, nor on measures of distortionary policies, but I do find that aid increases the size of government. Government consumption rises by approximately three quarters of total aid receipts.

The main aim of this paper is to examine measures of distribution as proxied by human development indicators. Since infant mortality indicators respond quickly to higher consumption and improved health services, infant mortality can be considered a "flash" indicator of improvements in economic conditions of the poor. I find no significant impact of aid on improvements in infant mortality, primary schooling ratios nor life expectancy. I argue this is strong evidence that aid flows primarily benefit a wealthy political elite.

These results may be biased since I am aggregating a range of political regimes. So in the final set of empirical tests I examine whether different political regimes use aid differently. I allow for a differential impact of aid in liberal democratic regimes and according to a ranking of political liberties. But my empirical results reject the hypothesis that democratic/liberal regimes use aid differently. Under each regime all aid is used for consumption, and there is no significant impact of aid on human development indicators.

But there is one important caveat to these findings. I do find that democratic/liberal political regimes, ceteris paribus, have $30 \%$ lower infant mortality. I interpret this as evidence that the poor are more empowered in these regimes, and this induces governments to provide more basic services. But once conditioning on these different regimes, my results suggest that all political systems support a high income political elite. So it is not surprising that aid benefits this elite.

The remainder of this paper is organized as follows. Section 2 presents my analytical framework. Section 3 outlines empirical tests based on reduced form equations from this model. Sections 4, 5 and 6 
discuss data sources, the determinants of aid flows, and my choice of instruments and specification tests respectively. Section 7 presents empirical results using aggregate aid flows, and section 8 allows for differences across political regimes. Section 9 concludes.

\section{Public Choice Under Alternative Political Regimes}

The debate over the effectiveness of foreign aid centers on the role of the political regime in causing poverty. In this section I briefly describe a model of political behavior that encompasses cases where aid is effective and cases where aid is ineffective, a full derivation of the model is given in Appendix 2. My starting point is to make specific assumptions about the goals of a political regime, and I then examine economic outcomes and the effectiveness of aid under different regimes. The reduced form equations from this model motivate my empirical work.

I consider a world with many countries all growing at some constant rate $g$ along a steady state growth path. Each country has politicians that choose macroeconomic policies to maximize welfare of their political elite, and Ramsey style households take these policy choices as given when they make optimal consumption and investment decisions. I want to use this framework to examine why some poor countries remain relatively poor, and do not grow faster and "catch-up" to the high income countries, so throughout this section I solve for steady-state outcomes and I drop all time subscripts. I begin by defining the politician's maximization problem, and then I briefly outline familiar producer and consumer problems. In the final subsection I characterize predicted effectiveness of aid and the cross section pattern of national incomes according to political regime types.

\subsection{The Politician's maximization problem}

The political regime is determined by the type and breadth of persons that politicians take into account when choosing government policies. In each country the political regime maximizes the welfare of a fraction, $\mathrm{s}^{*}$, of the population which from hereon I call the political elite. 
The members of the political elite are identical, the total (mass of the) population in each country is normalized to equal one, and I'll index each citizen using subscript s over the interval [0,1]. Households differ according to their labor endowment, $1_{\mathrm{s}}$, and the sum of all labor is normalized to one.

The role of the government is to finance productive public goods but it can also make non-productive transfers to the elite. Politicians use distortionary financing, here a proportional income tax, $\tau$, to raise funds to finance public goods, G, and to carry out lump sum and strictly positive transfers, $t_{\mathrm{s}}$. Governments can also receive foreign aid. In order to keep the framework as simple and realistic as possible, I'll assume this aid is fungible and the government can allocate the funds as needed. I'll also assume that the aid is not conditional, ${ }^{5}$ so that the policy choices and political regime of the nation are not directly affected by aid flows. ${ }^{6}$ In the final subsection and in the empirical parts of this paper I discuss some of the implications of introducing conditional aid.

The problem for the political leader is to maximize weighted sums of utility, $u(A$, of the political elite subject to the government's budget constraint:

$$
\max _{t_{s}, \tau, G} \int_{l_{s}^{*}}^{1} \psi(s) u\left(c_{s}\right) \partial s
$$

subject to:

$$
\tau Y+F \quad G=\int_{0}^{l} t_{s} l_{s} \partial s \quad t_{s} \geq 0
$$

$\mathrm{c}_{\mathrm{s}}: \quad$ consumption of individual $\mathrm{s}$

F: $\quad$ foreign aid to the government

G: expenditures on public goods and services

Y: national income excluding foreign aid

$1_{s}$ : $\quad$ labor endowment of person $\mathrm{s}$

$\mathrm{t}_{\mathrm{s}}$ : $\quad$ transfer per effective labor unit to person $\mathrm{s}$

$\mathrm{u}(\mathrm{c})$ : utility of person consuming $\mathrm{c}$

$\tau$ : $\quad$ income tax rate 
$\psi(\mathrm{s})$ : $\quad$ political weighting of household $\mathrm{s}$

There are two parameters of this welfare problem that characterize the political regime. First, the value of $s^{*}$ determines the broad-based representativeness of the government. If $s^{*}=1$ then the policy maker maximizes welfare of the sum of all citizen's utilities. But as $\mathrm{s}^{*}$ approaches zero the politician becomes a pure elitist dictator.

The second factor that determines the regime type is the composition of the political elite. Some people are born lucky with high endowments of labor/skills, $1_{s}$. An egalitarian regime maximizes the welfare of a group with low initial labor endowments, while an elitist regime will choose the group independent of its labor supply, or it may be composed of only well endowed citizens. I assume that the government only uses transfers, $t_{s}$, to target benefits to these political supporters, and for convenience I assume it weights all members of this elite equally ( $\psi$ constant $).^{7,8}$

\subsection{Households}

The problem facing each household is to choose its consumption and savings profile so as to maximize welfare given the policy variables, $\tau$ and $\mathrm{G}$, and any transfers they receive. A typical household $\mathrm{s}$ produces goods using a Cobb-Douglas bundle of human and physical capital and labor:

$$
y_{s}=k_{s}^{\alpha}\left(A \bullet l_{s}\right)^{\beta}\left(G \bullet l_{s}\right)^{\gamma} \quad \alpha+\beta+\gamma=1
$$

where I am assuming that each household benefits from government services in proportion to their initial labor endowment. The parameter A captures labor augmenting productivity which grows at rate g. A profit maximizing household will choose physical and human capital so as to equate its after tax marginal product of human and physical capital with real interest plus depreciation costs.

To keep the problem simple and familiar I assume households have Ramsey-type time separable utility functions with constant discount rate $\delta$, and an intertemporal elasticity of substitution, $1 / \sigma$. In this framework 
the consumer's euler equation will tie down the real interest rate in the steady-state so that:

$$
r=\sigma \bullet g+\delta
$$

We can now combine this condition with the first order conditions determining the consumer's optimal choice of physical and human capital inputs to express household income as a function of policy variables and exogenous parameters:

$$
y_{s}=\alpha^{\frac{\alpha}{\beta}} A(1 \tau)^{\frac{\alpha}{\beta}}(\sigma g+\delta+\rho)^{\frac{\alpha}{\beta}} G^{\frac{\gamma}{\beta}} l_{s}=Y(\tau, G) l_{s}
$$

The right hand side of (5) shows that steady state household production is a linear function of labor endowment, and a constant fraction of national income, $Y$. Each country grows at rate $g$ because they can benefit from world exogenous labor productivity which grows at $\mathrm{g}$. But nations will have different income levels when policy variables are different. National income rises with productive government spending and declines with distortionary taxes.

In the steady state each household will purchase sufficient new capital to cover depreciation, $\rho$, and to finance new investment to match productivity growth, $\mathrm{g}$. Any remaining disposable income and transfers will be used for consumption, $\mathrm{c}_{\mathrm{s}}$, so:

$$
c_{s}=\left[\theta(1 \tau) Y(\tau, G)+t_{s}\right] l_{s}
$$

where $\theta$ is the proportion of a household's production that is used to finance investment: $\theta=1-(g+\rho) \alpha / r$.

\subsection{Optimal tax, spending and transfer policies}


Politicians must maximize (1) subject to (2) and (6). The solution characterizes the steady state path for government spending, distortionary taxes, and lump sum transfers.

With Cobb-Douglas technologies the optimal level of government spending will be a constant fraction of income:

$$
\frac{G}{Y}=\gamma
$$

This is what Barro (1990) calls the productive efficiency condition.

The cross country pattern of taxes and transfers is determined by one parameter. This parameter, $\mathrm{L}\left(\mathrm{s}^{*}\right)$, is the sum of the individual labor endowments of each member of the elite, and it measures the political elite's share of the productive resources in the economy. ${ }^{9}$ When the political elite is highly representative, so that their share of resources in the economy is large, then politicians will have less incentive to introduce distortionary policies that reduce national income. The elite gains when distortionary taxes are introduced because they receive the additional revenues as transfers, but these taxes are costly since the distortions also reduce household income.

The optimal tax rate will be determined in two stages. First the government must decide whether to enter into a transfer program. When choosing to introduce higher taxes in order to finance transfers, politicians must compare the marginal benefit of one additional unit of transfers with the marginal cost of raising that transfer. But since it is always optimal to have some taxation to finance government expenditures, the marginal cost of raising one unit of finance is always strictly greater than one unit. This wedge between the costs and benefits means that after financing the optimal level of public goods, the government will only choose to enter into a transfer program if there is a sufficiently strong desire to redistribute, ie the parameter $\mathrm{L}\left(\mathrm{s}^{*}\right)$ must be smaller than some threshold level L. There are therefore two regions for the optimal tax rate depending on whether the representativeness of the political elite is less than or greater than this threshold: 


$$
\begin{gathered}
\tau=\gamma \frac{F}{Y} \quad \text { if } L\left(s^{*}\right)>\bar{L} \\
\tau=1 \alpha \frac{\theta L\left(s^{*}\right)}{1 \theta L\left(s^{*}\right)} \text { if } L\left(s^{*}\right)<\bar{L} \\
\bar{L}=\frac{1 \alpha \gamma \frac{F}{Y}}{\theta\left(2 \alpha \gamma \frac{F}{Y}\right)}
\end{gathered}
$$

where:

Figure 2A graphs the optimal tax policy as a function of the representativeness of the political elite. The labor share at the intersection of (8) and (9) shows the threshold level where the political regime chooses a tax policy identical to Barro's benevolent dictator. I define this as a Laissez-Faire regime since the government does not enter into a transfer program. Below this threshold taxes and transfers rise. Egalitarian and elitist regimes are defined as outcomes where politicians choose to enter into a transfer program.

Figure 2B shows that these regimes will use foreign aid differently. A rise in foreign assistance permits the Laissez-Faire government to reduce distortions, and as shown in equation (8) a Laissez-Faire government would reduce taxes by the same amount as transfers. This is shown on Figure $2 \mathrm{~B}$ as a shift downward in the tax rate. But this is not the case for egalitarian and elitist regimes. These regimes have already chosen the tax rate to equate the benefits and costs of distortionary taxes, and as shown in equation (9) these benefits and costs are not affected by receiving additional lump sum financing from abroad. Egalitarian and elitist governments use foreign assistance to increase transfers but they do not change distortionary policies. 


\subsection{National accounts and political regime shifts}

We can now derive equations for national accounts and distortionary policies as a function of foreign aid receipts. The predicted impact of foreign aid under alternative political regimes can be used to derive empirical tests. We can also examine how political regimes shifts change macroeconomic outcomes.

To derive equations for the national accounts it is useful to express

$$
\tau=\tau_{s}^{*} \omega \bullet \frac{F}{Y}
$$

optimal tax policy as a general rule:

where $\omega=0,1$ for an elitist/egalitarian or laissez-faire regime respectively, and $\tau_{\mathrm{s}^{*}}$ is the initial level of taxes prior to aid receipts (which depends on the labor supply of the elite indexed here by $\left.s^{*}\right)$. We can solve for the average propensity to consume, investment ratio and national income by aggregating consumption, investment and income over all households:

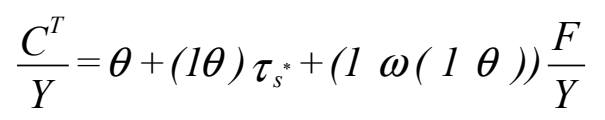




$$
\frac{I}{Y}=\left(\begin{array}{ll}
1 & \theta
\end{array}\right)\left(\begin{array}{ll}
1 & \tau_{s^{*}}
\end{array}\right)+(1 \theta) \omega \frac{F}{Y}
$$

Figure 3 graphs the cross section of national incomes when we allow the representativeness of government to vary. The vertical axis shows income per capita relative to income in a country with a laissez-

$$
Y=\alpha^{\frac{\alpha}{\beta}} A \tau^{\frac{\alpha}{\beta}} \frac{\gamma}{\gamma^{\frac{\gamma}{\beta}}}\left(1 \tau_{s}^{*}+\omega \frac{F}{Y}\right)^{\frac{\alpha}{\beta}}
$$

faire government. When there is no foreign aid, national income depends on tax rates, and tax rates rise as the government becomes less representative. When distortions rise the incentive to invest falls, and in general equilibrium savings rates also fall. Mankiw, Romer and Weil (1992) argue that the positive correlation between savings and income in cross country data is evidence in favor of the Solow model, but here this correlation is driven by greater investment opportunities in those countries with less distortionary policies. Cross country patterns are driven by underlying differences in political regimes.

The poor countries in this model are nations that have governments which have chosen to enter into transfer programs. Since these politicians will use aid flows to increase transfers rather than reduce distortions, foreign assistance does not raise income or investment - it is used instead to raise consumption. But even when aid is consumed it may not be wasted. There are two types of poor nations at any point such as B on the graph. An egalitarian government at point B transfers foreign aid to the poor, so aid may still be successful at reducing poverty. An elitist government transfers funds to a political elite. Only elitist governments waste aid as described by Bauer (1971) and Friedman (1958).

This framework also shows one way political regime shifts can affect macroeconomic variables. If the government becomes more representative, so that it shifts from point A to point B on Figure 3, then both the savings rate and income of that country would rise. The more representative government would reduce economic distortions and improve policies so that the country would grow faster and catch-up to 
wealthier nations. Alteratively, even if governments remain at point B but a revolution installs a more egalitarian government, then poverty indicators will improve and income distribution will become less skewed since the new governments will direct transfers to the poor.

This interpretation of political regime reflects one line of the debate over foreign assistance. In this model long term assistance will not succeed unless it is conditional on policy changes, and if the conditionality succeeds we can expect aid to correlate with growth as the country catches up to its high income neighbors. Short term aid programs that support better political regimes can also be expected to improve poverty indicators so long as they help lay the political foundations for economic reforms that support the poor. But if aid programs are unrelated to political reforms, or they are ineffective at imposing conditionality, then this model predicts aid will not lead to growth or catch-up and aid would not benefit the poor. These observations motivate my empirical tests in the next section.

So far I have not explicitly modeled the reasons countries give aid, but it is easy to see how permanent transfers could be realistically justified. If altruism motivates aid then rich countries will permanently give to poor countries. As long as relative incomes are constant in the steady-state, suitable conditions on altruism will ensure that aid is permanent. Alternatively, if aid is better represented by a market where countries buy and sell influence, say for example votes at the United Nations, then as long as rich countries consume more votes than poor countries, transfers will go from rich to poor. With suitable restrictions on preferences, in the steady state aid/the price of votes will grow at the same rate as income.

\section{Empirical Tests}

My empirical tests will be based on the null hypothesis, in line with the arguments of Bauer (1971) and Friedman (1958), that politicians will use aid for transfers and not for growth producing reductions in internal distortions. Under the null hypothesis both domestic income and growth rates are independent of foreign aid. 
The first test is to ask whether aid receipts have permitted governments to reduce or eliminate distortionary policies. This test can be based on a general solution for the tax rate:

$$
\tau_{j}=\bar{\tau}+\beta^{\tau} \frac{F}{Y}+\mu_{j}+\varepsilon_{j t}
$$

where $\beta^{\tau}$ is a regression coefficient, $\mu_{\mathrm{j}}$ is a country specific random term, and $\varepsilon_{\mathrm{jt}}$ is a white noise error term. Once I properly instrument for aid, I can test the null hypothesis $\mathrm{H}_{0}: \beta^{\tau}=0$. My interpretation of distortions is not taxes per se, but the whole framework of distortions introduced by many governments. Since these are generally not measurable, this test can be based only on direct tax measures or indexes of distortionary policies.

The second test examines the indirect impact of reduced distortions by testing for changes in consumption and investment, and it can also be interpreted as a test of the importance of capital shortage in restricting investment. I estimate (12) and (13) using long averages of national accounts data, allowing for a country specific random error and time dummies. The regression equations are as follows:

$$
\frac{C^{T_{j}}}{Y_{j}}=\frac{\bar{C}}{Y}+\beta^{C} \frac{F_{j}}{Y_{j}}+\mu_{j}+\varepsilon_{j t}
$$

with the null hypothesis that $\mathrm{H}_{0}: \beta^{\mathrm{C}}=1$ and $\mathrm{H}_{0}: \beta^{\mathrm{I}}=0$. Note that these equations are not independent, so the sum of the coefficients on aid in the investment and consumption equations should equal one. My regression results will be biased if aid flows are correlated with other

$$
\frac{I_{j}}{Y_{j}}=\frac{\bar{I}}{Y}+\beta^{I} \frac{F_{j}}{Y_{j}} \mu_{j} \varepsilon_{j t}
$$


capital inflows, or there is measurement error in the aid data. I can test for this by examining if the sum of these two coefficients is significantly different from one.

The third set of empirical tests examines who benefits from aid. This allows me to differentiate between egalitarian and elitist regimes. The best widely available indicators of poverty are infant mortality, life expectancy and primary schooling ratios. Here I examine whether governments used aid receipts to benefit the poor. I do this by running regressions of the log difference of these indicators on initial conditions,

$$
\Delta \log \left(X_{t}\right)=\bar{X}+\beta_{0} X_{t l}+\beta_{1} \log \left(X_{t l}\right)+\beta^{X} \frac{F}{Y}+\mu_{j}+\varepsilon_{j t}
$$

and the aid GNP ratio properly instrumented:

An elitist regime allocates all aid to a wealthy elite, so human development indicators will not change: $\beta^{\mathrm{X}}=0$. I chose log differences here rather than levels because investments in health care and education take time, and I allowed for non-linear response to initial conditions since the potential improvements in indicators will depend on starting values. If the poor benefit directly from aid, they can invest in better housing, education, sanitation and nutrition. Infant mortality will improve quickly if the government invests in public health services targeted to the poor. ${ }^{11} \quad$ Finally, the fourth set of tests examines whether certain political regimes use aid more effectively than others. I do this by interacting foreign aid with indexes of political liberties in each of the above regressions. If democracies or liberal political regimes use aid more effectively to benefit the poor then the interaction term between aid and political liberties should show these benefits.

\section{Data Sources and Definitions}

To implement these tests I use data on net Official Development Assistance (ODA) published by the OECD. ODA is defined as all transfers from official sources with at least a $25 \%$ grant component but in practice is virtually all grants (the grant component averaged $93 \%$ 
during the sample period). They only include aid aimed at improving human or economic welfare so military assistance is excluded. Table 1 describes the allocation of aid according to use and donor. Approximately $30 \%$ of aid is cash transfers, and another $10 \%$ are untied balance of payments support (not shown). Emergency aid is only a small fraction of total flows, and bilateral aid makes up approximately three quarters of all ODA. In summary, aid is a large and highly fungible source of assistance to recipient countries. ${ }^{12}$

The national accounts data and human welfare indicators are from the World Bank and Summers and Heston data base. I use the World Bank measure of dollar GNP since this is primarily based on market exchange rates, and I need to measure the value of aid at market prices. The World Bank GNP excludes official transfers which is the same concept I used in the analytical part of this paper.

Throughout this paper I present results using a base sample of countries in decade averaged data common to the World Bank, Summers and Heston and the OECD data base. I use five year and decade averaged data in order to eliminate business cycle factors and measurement error. Any benefit from using annual data is diminished because the best instruments for permanent aid flows change slowly over time. I then exclude OPEC countries since they both give and receive aid during this sample period. I also exclude Israel since it is arguably a special case. On examining the data there were four observations with measurement error described in an endnote. ${ }^{13}$ Any other exclusions are due to missing observations.

The BASE SAMPLE is composed of the remaining 96 countries including all observations where the recipient's aid was less than $15 \%$ of GNP. In the derivations of Section 2, I assumed that aid was fungible if aid is not fungible than aid will certainly raise investment since some $40 \%$ of aid is directed to investment projects. As discussed in the empirical section, I exclude the 14 observations with AID/GNP ratios greater than $15 \%$ because it appears that beyond these levels aid is no longer fungible. I compare results using this base sample to the FULL SAMPLE where all observations are included.

\section{The Motives for Giving Aid}


Despite the popular belief that aid is primarily motivated to assist the poor, substantial evidence points to political, strategic, and welfare interests of donor countries as the driving force behind aid programs.

Studies by Maizels and Nissanke (MN, 1984), McKinlay and Little (ML, 1977, 1978a, 1978b, 1979), Mosley (1985,1987), Frey and Schneider (1986) and Trumbull and Wall (1994) analyze the determinants of foreign aid using cross-country regressions. The series of studies by ML and MN focus on bilateral aid patterns and they attempt to measure whether "recipient needs" or "donor's interest" are they key factors motivating international aid flows. They do this by including variables which measure donor interest, such as proxies for military importance of the country, whether it was a former colony, and measures of recipient needs such as quality of life indicators and income per capita. The studies broadly conclude that aid flows primarily reflect donor's interests rather than recipient needs. ${ }^{14}$

Both ML and MN also examine each donor's motives for giving aid. ML concludes that the greatest part of the variance in US aid flows can be explained by military and strategic factors. They find that British and French aid goes to countries that were former colonies, and countries where these donors have historically strong trade relations and investment interests. OPEC aid is given to neighboring countries and favors members of the Arab League.

Table 2 shows my own regressions measuring cross-country determinants of aid. The table shows results using alternative subsamples, right-hand side variables, and regression techniques. Regression I shows that $65 \%$ of the variance in decade averaged aid flows is explained by income per capita and population alone. A $10 \%$ increase in population reduces the aid/GNP ratio by 0.0032 , while a $10 \%$ rise in per capita income reduces the same ratio by $0.0036 .^{15}$

In regression II, I allow for regional effects, external shocks measured by the cumulative sum of terms of trade shocks over the decade, and a Paris Club dummy set to one in 1981-90 if the country entered into debt rescheduling negotiations. None of these variables is significant. I also include per capita growth which has a small positive coefficient and is insignificant. 
The variables titled "Friends of US" and "Friends of OPEC" are political dummies aimed at capturing the importance of the country to a particular donor. These dummies are set to one if the country receives more than $1 \%$ of the total aid budget of the donor. The US Congress must vet every aid allocation, and therefore large nominal amounts must be determined by political rather than need-based factors. Large OPEC aid disbursements are primarily to neighboring Arab countries. "Friends of France" is set to one for members of the Franc zone reflecting France's special relations with her former African colonies. These variables are generally significant after controlling for regional dummies, and other factors that would influence aid flows.

In regression III, I include the aid/GNP ratio lagged twice and income per capita as regressors. The twice lagged aid/GNP ratio should be uncorrelated with business cycle disturbances but correlated with the political determinants of aid that are relatively permanent.

In regression IV, I include two variables that capture human development indicators as proxied by start of period infant mortality and life expectancy. Neither coefficient is significant, showing that once I control for income per capita, aid flows are not directed to countries with poor human development conditions.

Regression $\mathrm{V}$ estimates the equation allowing for country specific fixed effects. In this case the population term becomes insignificant though the sign remains negative. This probably reflects the small variance of population growth in the data, and the fact that population is more a proxy for size of the economy rather than the actual number of bodies.

There are several reasons why size of country may be an important determinant of aid flows. First, both international institutions and bilateral donors are hesitant to transfer large nominal amounts to any one country for political reasons. Large nominal transfers will come under much greater public scrutiny than relatively smaller amounts. Second, there are minimal amounts that can be transferred due to fixed costs of entry. Mosley et al (1991) reports that the World Bank's loan procedures effectively favor small countries for this reason. Third, it maybe that small countries have relatively more influence for sale, taking into account size, than larger countries. The most trivial example of this 
would be the sale of votes at the United Nations. If an international market develops for these votes, then small, poor countries would sell votes to large rich countries. This would lead to a negative correlation between aid and both income per capita and population in cross country regressions. Finally, small countries may be more willing to sell their influence. Small countries may gain more from joining a coalition than by acting independently.

Table 3 shows that aid flows have a large permanent component. Here I report results from estimating time trends for the aid/GNP ratio of each country separately. Using these time trends, I project that only $20 \%$ of recipient countries will receive zero aid within 50 years but slightly less than one half of the countries have significant time trends between 1981 and 1990.

For the remainder of this paper I will focus on three key findings. First, political factors largely determine aid flows. I will use the political proxies and size of country to form alternative instrument for aid flows. Second, the motivations for giving aid vary by donor. This will allow me to conduct instrument robustness tests by examining the impact of aid when alternative donors (with varying motives for giving aid) are excluded from the sample. Finally, aid flows have a large permanent component, so I will treat them as permanent transfers. I test for measurement error resulting from this assumption by excluding those countries where aid is predicted to decline to zero in the next twenty years.

\section{Instruments and Econometric Implementation}

In my empirical work I use three different instruments and then conduct a series of robustness and sensitivity tests. Each instrument has strengths and weaknesses, so I compare results using alternative instruments and also conduct robustness tests as described below.

The first instrument is the logarithm of population. As described above small economies receive more aid than larger economies for political and structural reasons. Certain endogenous growth models predict that large countries grow faster than small countries due to economies of scale. But empirically this does not seem to be a relevant issue. With reasonably free trade, low transport costs, capital mobility, 
and inexpensive communications it is hard to see how largeness provides any clear benefits. The actual economic success of many small countries reinforces this point.

The second instrument directly captures the political determinants of aid flows. I use three variables to capture interests of major donors with clear political agendas. These are the variables described above: Friends of US, Friends of OPEC, and Friends of France. In these regressions I also control for other determinants of aid flows, so the instruments capture large aid flows from donors after controlling for income, growth rates, etc. These instruments are valid if the recipient countries receive these large aid flows purely for political reasons. The instruments would be invalid if large bilateral aid was driven by factors related to country need that I have not controlled for. My assumption here is that the US, French and OPEC countries give this aid for political motives.

The final instrument is twice-lagged aid (here I use five year averages of data). Lagged aid should be uncorrelated with emergencies and business cycle factors while correlated with the long term political and strategic factors that make some countries high aid recipients. This makes it a good candidate as an instrument, but several caveats should be taken into account. Business cycle factors could introduce a spurious correlation between aid and national accounts over the business cycle. This is particularly true of shocks that cause temporary fluctuations in the real exchange rate such as fiscal spending financed by foreign borrowing. ${ }^{16}$ To limit this sort of spurious correlation I use two lags of aid. A second caveat is that high aid/GNP ratios may reflect more fundamental problems that cause poverty in recipient countries. To the extent that these problems persist over long periods of time, then lagged aid will be correlated with these fundamental factors. In this case population and the political instruments described above will serve as alternative means to test robustness of the results.

I compare the results from these IV regressions with OLS regressions where I control for income levels, terms of trade shocks, and other important country characteristics. These OLS regressions also allow me to test whether aid from different donors has different impacts and therefore biases my results. For example, Papanek (1972) argues 
that US assistance is directed to strategically important countries and these countries may have other characteristics, such as high tax rates to finance military expenditures, that will affect investment and savings. It is also possible that US aid is allocated differently from other aid, so that it has a different impact on national accounts and poverty indicators. I can test the robustness of my results to these potential biases by running regressions where I include both US aid and all aid as right hand side

$$
\frac{C_{j t}}{Y_{j t}}=\frac{\bar{C}}{Y}+\beta^{A L L} \frac{F_{j t}^{A L L}}{Y_{j t}}+\beta^{U S} \frac{F_{j t}^{U S}}{Y_{j t}}+\mathrm{B}^{Z} Z_{j t}+\mu_{j}+\varepsilon_{j t}
$$

variables:

and then testing the null hypothesis: $\beta^{\mathrm{US}}=0$. The $\mathrm{Z}$ variables are a set of control variables that I include in each regression. The null hypothesis is a joint test that United States aid has the same impact as other country's aid, and that American aid is uncorrelated with specific characteristics of the country.

\section{The Aggregate Impact of Aid Flows}

I begin this section by summarizing my main findings and I discuss robustness and sensitivity tests. The second subsection analyzes the impact of aid on human development indicators.

\section{7a. Main finding and robustness tests}

Table 4 summarizes 76 regressions using alternative instruments, $Z$ variables, and samples and regression techniques. Each cell shows the coefficient on the AID/GNP. In every case the sum of the estimated coefficients in the consumption and investment equations is insignificantly different from one, so I can conclude that aid receipts are not correlated with other capital inflows.

The estimates in column one capture my general findings. The control variables in this regression are income per capita, per capita growth, and regional dummies and measures of external shocks. The full regression results are shown for reference in Table 5. ${ }^{17}$ 
The estimated parameters are consistent with an elitist political regime. The marginal propensity to consume from aid (public and private) is insignificantly different from one, and the marginal propensity to invest is insignificantly different from zero. The point estimates show that approximately three quarters of aid is used to raise public consumption, and one quarter goes to private consumption. It is interesting to note that these results are similar to the findings in the early literature on aid and savings such as Griffin (1970) and a more recent paper by Levy (1987). These authors did not attempt to instrument their data, and as can be seen from this table, the expected simultaneity bias disappears once we control for income levels in OLS regressions.

Given that government spending rises by three quarters of aid flows, it is not surprising that there is no impact of aid on taxes. Only two tax measures are available for the countries in my data set. These are the inflation tax (the average percentage change in the GDP deflator divided by 100) and indirect taxes net of subsidies expressed as a fraction of GNP. Each coefficient is insignificant and the signs vary across regressions. In order to capture whether aid correlated with improvements in basic policy indicators, I also ran regressions using the black market exchange rate premium as an index of policy distortions. In every case the impact of aid is insignificant and generally has the wrong sign.

While consumption does rise, there is no evidence that the poor benefit from aid. The coefficient on aid in the infant mortality equation has the right sign but is small. It predicts that annual aid flows of $10 \%$ of GNP will reduce infant mortality by $2 \%$ over the decade. The coefficient on primary schooling has the wrong sign, and there is no clear impact on life expectancy.

In summary, the results imply that most or all aid goes to consumption, it increases the size of government, and does not benefit the poor. The remaining columns use alternative data samples and instruments to test the robustness of these results.

The second column shows that when I only control for income per capita the results do not change. The third and fourth columns show 
results when I instrument aid using the instruments described in the previous section.

Column three reports results when I instrument aid directly using the $\log$ of population as an instrument. Here the basic results do not change but the coefficient on the inflation tax is larger though it is still insignificant. It implies that countries that receive aid equal to $10 \%$ of GNP have on average 69\% lower inflation. This almost certainly captures the impact of Latin American countries that are relatively large, and receive little aid. Column four shows similar findings when I instrument aid including proxies for political interest of donor countries.

The fifth column shows aid does have an impact on investment when I use the FULL SAMPLE. This is the only regression where the coefficient on investment is significant. This sample adds 14 observations for small countries where the aid/GNP ratio ranges from 0.15- 0.54. These are small countries where one large investment projection can equal $50 \%$ of GNP. ${ }^{18}$ These large investment projects would not be fungible, so the high coefficient on investment will reflect the impact of directed aid programs. It may also be easier for donors to monitor projects in very small countries, or the projects they choose maybe less fungible given the size of the economy. When small amounts of aid are used, as in the base sample, it is easier for recipient governments to effectively redirect aid. Column VI restricts the sample to those countries with aid/GNP ratios less than 0.1 . Here I find similar results as in the base sample. ${ }^{19,20}$

The last two columns test for robustness using five year data averages and alternative regression techniques. In theory I prefer longer time averages in order to smooth out temporary shocks. As I reduce the sample averages, I increase the transitory component of the variance in aid flows. This will lower the estimated propensity to consume from aid since optimizing consumers will consume only a fraction of temporary income. Likewise optimizing governments should smooth distortionary taxation. The basic conclusions do not change in five year data, providing some evidence that the permanence of transfers is not an important source of measurement error. To further test for permanence, I also ran regressions excluding the 21 countries which I project in Table 
3 will receive no aid by 2010 . None of the empirical results changed using this subsample. ${ }^{21}$

Column VII shows results when I use twice-lagged aid as an instrument. In this smaller sample the coefficient on total consumption rises, but the implied share of aid going to investment remains small. The last column shows the findings are robust when I allow for country specific fixed effects. These results are sensitive to the control variables that are included and the coefficient on investment is much higher if only income per capita is kept as a control variable. One problem with this estimator is that by extracting the fixed effect I leave only the time series variation in aid, this may increase the relative variance of transitory aid components in the data.

Lastly, Table 6 reports test statistics from my robustness tests. My procedure is described in (19). The table shows the t-statistics on each donor's aid in regressions using the full set of control variables shown in Table 5. Out of 54 cases, 3 are significant at the $1 \%$ level, 1 is significant at the $5 \%$ level, and 4 are significant at the $10 \%$ level. While the number of significant terms is more than should be expected, it turns out that four of these cases are on coefficients showing the division between public and private consumption. As described in an endnote, some countries allocate more aid to private consumption than others. ${ }^{22}$ Table 6 suggests this may reflect how each donor allocates aid since the division between private and government consumption appears to vary by donor. This may reflect differences in how each donor allocates aid. But Table 6 also shows that the coefficients on the main variables: total consumption, investment and infant mortality are robust. The remaining significant coefficients show no consistent pattern across indicators, so I suspect they represent spurious correlation.

\section{7b. Government failure}

The lack of impact of aid on human development indicators, and particularly infant mortality, is strong evidence of government failure. Aid could influence infant mortality either directly through higher consumption of the poor, or indirectly through greater provision of public services to the poor. 
Survey data shows that in less developed countries the poorest $60 \%$ of the population earn $26 \%$ of national income. ${ }^{23}$ If a country received aid equal to $10 \%$ of GNP, and if all aid were allocated to the bottom three quintiles of income earners, the income of this group could potentially rise by $38 \%$. Based on the cross country relation between infant mortality and income, this could reduce infant mortality by roughly $20 \%{ }^{24}$ Instead my estimates predict infant mortality falls by 2 $3 \%$, and there is no evidence in cross section data (see table 2 ) that high aid recipients have better initial levels of infant mortality. This shows that the poor receive very little of the benefits of aid programs.

Figure 4 shows that governments can improve these indicators when they are determined to do so. Figure 4 is a component plus residual plot. The vertical axis shows the sum of regression residuals and the component of the change in infant mortality that can be explained by foreign aid. These are plotted against the aid/GNP ratio of the recipient. Here I use the regression in Table 5 but with data averaged over twenty years. Chile and Costa Rica are two outliers in the left corner of this plot. These two countries are famous for their directed health programs aimed at improving infant mortality and general health indexes. $^{25}$ The World Bank (1993) estimates similar programs would cost $3.1 \%$ of GNP in low income countries. The lack of correlation between aid and health indicators shows that foreign aid does not introduce incentives into recipient countries to improve human development indicators. It also shows that financing is not the main constraint barring countries from improving human development indicators.

\section{Do Alternative Political Regimes Use Aid Differently?}

My regressions may be biased because I have pooled together nations with very different political regimes. Indeed, some aid advocates argue that aid should only go to countries with "good" political regimes since these are the countries that will use aid effectively.

In this section I test whether alternative political regimes use aid differently, and I also test whether different political regimes are more successful at relieving poverty. I use two different categorizations of regime types. First, I use an index of political liberties published by 
Gastil (1989). This is an ordinal ranking of political liberties based on country surveys. I invert their scale so the index ranges from 0.142 to 1.00 in ascending order of political liberties using the measure for the middle of each decade. The second index is a dummy set to one if the country is a liberal democracy according to Derbyshire and Derbyshire (1989) throughout the whole sample period, and zero otherwise.

My first set of tests examines whether different political regimes use aid differently. I run each regression from the first column of the summary table 4, now including an interaction term with foreign aid, and an own effect as a proxy for the possible impact of political regimes. The coefficients on these variables are reported in Table 7.

The results show that liberal political regimes do not use aid any differently from the most repressive regimes. No interaction term or own effect term is significant at the 5\% level, and coefficients are generally small. $^{26}$

These findings suggest that all political regimes allocate foreign aid to a high income political elite. But it is interesting to examine whether different political regimes perform better in measures of basic human development indicators. In my framework political regime shifts or revolutions can lead to improvements in poverty indicators if the new governments are more egalitarian and more representative. Even though liberal democracies may still use aid in a similar manner as other regimes, they may still give more power to the poor. This power could induce governments to provide more basic services.

Table 8 shows that in this cross section of non-communist countries, liberal political regimes have roughly 30\% lower infant mortality, ceteris paribus, than the most restrictive regimes. The first column includes a dummy variable indicating political regime according to Derbyshire and Derbyshire's (1989) categorization. There are four political categories, and the point estimate in the first column shows that liberal democracies, ceteris paribus, have 32.8\% lower infant mortality than emerging democratic regimes (the excluded category) and $12 \%$ to $18 \%$ less than socialist and authoritarian regimes respectively. These results do not hold up within continents, for example in a regression with only African nations the coefficient on Gastil's index becomes slightly positive and insignificant. This may be due to the small sample, the 
remaining four columns show these results remain robust when I exclude particular continents.

I interpret the relatively low rates of infant mortality in liberal regimes as evidence of greater empowerment of the poor in these countries. Poor households probably have significantly more influence in a democratic country with a free press and free speech. This induces the government to make more efforts to provide basic services to these groups, and even small expenditures and efforts can have dramatic effects upon basic measures of poverty and health as described above. But even in a democratic regime the poor are bound to be weak in the political process. It may be difficult to coordinate and mobilize the vote in the interests of the poor, and illiteracy and poor health must be important hindrances to political activity. The finding that democracies and liberal regimes do not allocate aid any differently from other regimes suggests that while the poor have enough additional power to gain better basic services in liberal societies, they continue to be weak relative to the political elite and hence only receive a small fraction of the benefits of aid. ${ }^{27}$

\section{Conclusions}

The aim of this paper was to relate the effectiveness of foreign aid programs to the political regime of recipient countries. I presented a simple analytical framework where poverty is caused or enhanced by distortionary policies introduced by politicians. In my framework, aid does not promote economic development for two reasons: Poverty is not caused by capital shortage, and it is not optimal for politicians to adjust distortionary policies when they receive aid flows.

Between 1971 and 1990 most long term aid was provided on a regular basis with little or no effective conditionality. I found this aid increased consumption but higher consumption did not benefit the poor. The point estimates in my regressions show there was an insignificant impact on investment in countries that received less than 15\% of GNP in aid, though standard errors on these estimates were large. I also found that aid had an insignificant impact on improvements in basic measures of human development such as infant mortality and primary schooling ratios. These results suggest that even while particular programs such as 
immunization and resarch can be effective, the bulk of long term aid programs have had little impact on human development and investment between 1971 and 1990.

My empirical results are consistent with a model where politicians maximize welfare of a wealthy elite, and consistent with the pessimistic predictions of Bauer (1971) and Friedman (1958). Past experience has proven it is possible to dramatically improve human development indiciators at low cost over a ten to twenty year period. Dreze and Sen (1989) argue that the failure of governments to reduce infant mortality and improve basic human development indicators reflects public choice. The findings in this paper suggest that aid programs have not substantially changed government's incentives to carry out these programs, nor have aid programs engendered or correlated with the basic ingredients that cause investment and growth.

These findings emphasize the need to better understand the potential role of aid as a tool in changing political incentives. Casella and Eichengreen (1995) examine the potential efficacy of aid in ending harmful wars of attrition between political actors, and Sachs (1994) concludes that short term aid has in the past played a key role in promoting stabilization and maintaining political stability. In my model aid can be effective when it is conditional on policy and/or political reforms, and it can be effective in narrow cases where aid is nonfungible.

I presented some evidence that political reforms alone can play an important role. In my empirical work I concluded that while at the margin all political systems allocate aid to the elite, liberal political regimes, ceteris paribus, have approximately $30 \%$ lower infant mortality than the least free regimes. This may reflect a willingness of liberal regimes to provide more of the basic, though inexpensive services that are needed to prevent famine and improve human development indicators. But it may also reflect other cultural factors or economic conditions that I was unable to control for in these regressions. My coefficient estimates imply that in order to achieve the same reduction in infant mortality through existing long term aid programs, donors would have to provide annual aid equal to $150 \%$ of GNP for ten years to the recipient country. 
One plausible implication is that short term aid programs targeted to support new liberal political regimes, and to encourage greater political and social liberties, may be a more effective means of promoting growth and reducing poverty than current aid programs. If these new regimes stay in power long enough to improve literacy, health care, and education then they may sufficiently empower the poor in the political system so that poverty reduction becomes self-sustaining. But alternatively, it may be that the underlying factors that support liberal regimes and poverty reduction are rooted in historical, cultural and institutional factors that are not affected by new governments. In this case, new liberal regimes will not survive, or they may not implement the basic policies needed to reduce poverty and promote growth. 


\section{ENDNOTES}




\section{APPENDIX 1}

\section{Definitions and Source of Regression Variables}

AID/GNP: $\quad$ Ratio of dollar aid from OECD to dollar GNP as measured by theWorld Bank

LGNPCAP: $\quad$ Log of per capita GNP measured relative to the high income OECD from the World Bank

Per Capita GNP

Average real GNP growth rate over the sample period fromWorld Bank

Growth:

Population Growth: Average population growth rate fromWorld Bank

Terms of Trade: $\quad$ Cumulative income gains/losses due to terms of trade changes measured as a fraction of GNP as calculated by the World Bank

Debt Rescheduling: Dummy variable set to one if the country entered into rescheduling agreements with the Paris Club between 1981 and 1990

Sub-Saharan Africa: Dummy set to one if the country is in Sub-Saharan Africa

Asia: $\quad$ Dummy set to one if the country is in Asia

Latin America: Dummy set to one if the country is in Latin America

Infant Mortality: $\quad$ Infant mortality per thousand births from World Bank

Life Expectancy: Life expectancy at birth from World Bank

Primary Schooling: Percent of eligible age children in primary schooling

Total Consumption: Ratio of public and private consumption to GNP from World Bank

Private

Consumption: $\quad$ Ratio of private consumption to GNP from World Bank

Investment: $\quad$ Ratio of public and private gross investment to GNP from World Bank

Public Consumption: Ratio of public consumption to GNP

Indirect Taxes: $\quad$ Ratio of indirect taxes net of subsidies to GNP from World Bank

Inflation Tax: $\quad$ Average percent increase in GNP deflator divided by 100

Political Rights Ascending ranking of political liberties ranging from 0.14 to 1 formed by Indicator: inverting Gastil's (1989) rankings of countries for 1976 and 1986

Democratic Regime: Dummy variable set to one if the regime is a liberal democracy according to Derbyshire and Derbyshire (1989).

Socialist: $\quad$ as above for socialist regimes and China.

Military,

Authoritarian and as above, all regimes other than emerging democracy.

other: 


\section{APPENDIX 2}

\section{A. Solution to the Politician's Optimization Problem}

This appendix derives the solution to the politician's maximization problem. I consider a world with numerous countries all growing at a constant rate, g, along a steady-state balanced growth path. Each country has a different political system, but all other parameters are identical. I drop all time subscripts for convenience.

The politician's role is to finance public spending and transfers using revenues from a distortionary income tax and foreign aid. He

$$
\max _{t_{s}, \tau, G} \int_{I_{s}^{*}}^{1} \psi(s) u\left(c_{s}\right) \partial s
$$

solves:

subject to:

$$
\tau Y+F \quad G=\int_{0}^{1} t_{s} l_{s} \partial s
$$

$\mathrm{c}_{\mathrm{s}}$ : consumption of individual $\mathrm{s}$

$\mathrm{F}$ : foreign aid to the government

G: expenditures on public goods and services

$\mathrm{Y}$ : national income

$1_{\mathrm{s}}$ : labor endowment of person $\mathrm{s}$

$\mathrm{t}_{\mathrm{s}}$ : transfer per effective labor unit to person $\mathrm{s}$

$\mathrm{u}(\mathrm{c})$ : utility of person consuming $\mathrm{c}, \mathrm{u}^{\odot}$ is concave and twice differentiable.

$\psi(\mathrm{s})$ : political weighting of person $\mathrm{s}, \psi(\mathrm{s})$ is continuous and twice differentiable.

$\tau$ : income tax rate

Each citizen is endowed with labor supply, $1_{s}$, and the sum across the population is one. Each member of the ruling coalition is identical with labor, $1_{\mathrm{s}^{*}}$, and a common value of $\psi\left(\mathrm{s}^{*}\right)$.

\section{A.1. Production}


A typical household s produces goods using a Cobb-Douglas bundle of human and physical capital, labor and government services:

$$
y_{s}=k_{s}^{\alpha}\left(A \bullet l_{s}\right)^{\beta}\left(G \bullet l_{s}\right)^{\gamma} \quad \alpha+\beta+\gamma=1
$$

where each household must self finance their own investments. A reflects exogenous labor augmenting productivity growth and grows at rate $\mathrm{g}$.

\section{A.2. Consumers}

Consumer's maximize time additive separable utility with discount rate $\delta$, intertemporal elasticity of substitution $\sigma$ :

$\max _{c_{v}} \int_{t}^{\infty} \frac{c_{v}^{l \sigma}}{l \sigma} e^{\delta(v)} \partial v$

subject to:

$$
\dot{k}_{s}=(I \tau) y_{s}+t_{s v} l_{s v} c_{s v}
$$

and transversality conditions:

$$
\begin{array}{ll}
\lim _{t \rightarrow \infty} k_{t} e^{l_{r} r, \partial \partial}=0 & \text { The consumer's euler } \\
& \text { equation is: } \\
& \frac{\dot{c}_{v}}{c_{v}}=\frac{1}{\sigma}(r \delta)
\end{array}
$$

In the steady state consumption must grow at rate $\mathrm{g}$, so the interest rate will be determined by solving (7) for $\mathrm{r}$.

Using (7) and combining the first order condition for the choice of capital stock, production of a household s can be written as a function of

$$
y_{s}=\alpha^{\frac{\alpha}{\beta}} A(l \tau)^{\frac{\alpha}{\beta}}(\sigma g+\delta)^{\frac{\alpha}{\beta}} G^{\frac{\gamma}{\beta}} l_{s}=Y(\tau, G) l_{s}
$$

tax rates and government spending:

where $\rho$ is the rate of depreciation on capital, and $\mathrm{Y}$ is national income. 
In the steady state each household will purchase sufficient new capital, $i_{\mathrm{s}}$, to cover depreciation and maintain a constant capital/effective labor ratio. Total disposable income will equal income $\mathrm{y}_{\mathrm{s}}$, less taxes plus transfers $t_{s} l_{s}$. Consumption then equals disposable income less savings:

$$
i_{s}=(g+\rho) k_{s}
$$

where I have solved for a reduced form consumption equation (11) by substituting for the optimal capital/output ratio from the Cobb-Douglas

$$
\begin{aligned}
c_{s} & =(1 \tau) y_{s}(g+\rho) k_{s}+t_{s} l_{s} \\
& =\left(\theta(1 \tau) Y(\tau, G)+t_{s}\right) l_{s}
\end{aligned}
$$

production function $\left(\mathrm{rk}_{\mathrm{s}}=(1-\tau) \mathrm{y}_{\mathrm{s}}\right)$ and substituting from (9) for own income with $\theta=1-(\mathrm{g}+\rho) \alpha / \mathrm{r}$.

The planners problem is to maximize (1) subject to (2) and (11). The first order conditions from this are:

$$
\begin{gathered}
\int_{I_{s}^{*}}^{l} \psi(s) \frac{\partial u}{\partial c} l_{s}\left[\theta y+\theta(1 \tau) \frac{\partial y}{\partial \tau}\right]=\lambda\left[\tau \frac{\partial y}{\partial \tau}+y\right] \\
\int_{I_{s}^{*}}^{l} \psi(s) \frac{\partial u}{\partial c} l_{s}(1 \tau) \frac{\partial Y}{\partial G} \theta=\lambda\left[\tau \frac{\partial Y}{\partial G}-1\right] \\
\tau Y+B \quad G=\int_{l_{s}^{*}}^{l} l_{s} l_{s}
\end{gathered}
$$




$$
\begin{aligned}
& \psi(s) \frac{\partial u}{\partial c} l_{s}=\lambda l_{s} \text { if } t_{s}>0 \\
& \psi(s) \frac{\partial u}{\partial c} l_{s}<\lambda l_{s} \text { if } t_{s}=0
\end{aligned}
$$

where $\lambda$ is the Lagrange multiplier on the government budget constraint. Equations (12) and (13) determine optimal government spending as

$$
\frac{G}{Y}=\gamma
$$

a function of the tax rate:

The optimal tax rate is found by solving (12) and (15) when transfers are operative, or (12) and (14) when they are not operative:

$$
\begin{gathered}
\tau=\gamma \frac{F}{Y} \quad \text { if } L\left(s^{*}\right)>\bar{L} \\
\tau=1 \alpha \frac{\theta L\left(s^{*}\right)}{1 \theta L\left(s^{*}\right)} \text { if } L\left(s^{*}\right)<\bar{L}
\end{gathered}
$$

where:

$$
\bar{L}=\frac{1 \alpha \gamma \frac{F}{Y}}{\theta\left(2 \alpha \gamma \frac{F}{Y}\right)}
$$

and the remaining equations are determined as described in the text. National consumption and investment can then be calculated by integrating each household's consumption and investment function, (A9) and (A11), and substituting for the government's budget constraint (A14). 


\section{TABLE 1}

\section{Basic Facts about Aid \\ (in the sample of 97 countries)}

\section{Average Aid/GNP ratio}

81-90: range $0.00-0.54$, sdev 0.112

71-80: range $0.00-0.35$, sdev 0.035

0.056

in Base Sample:

81-90: range $0.00-0.144$, sdev 0.039

0.042

71-80: range $0.00-0.146$, sdev 0.045

0.046

Grant component (1980)

0.93

Restrictions on Procurement (fraction by category):

Untied:

Partially tied:

0.71

Tied:

0.05

0.25

Uses of Aid (fraction by type):

Emergency Aid

0.05

Food aid

0.13

Social and Admin. Infrastructure

0.20

Program aid

0.06

Economic Infrastructure

0.32

Other

0.24

Sources of Aid

Multilateral

Bilateral (of which):

0.25

0.75

France

0.13

Japan

0.15

OPEC

0.07

United Kingdom

0.04

United States

0.18

Other

Aid as a fraction of GDP from Donor Countries

(members of DAC)

1970

0.34

1980

0.35

1990

0.34

Source: $\quad$ OECD (1992).

Note: $\quad$ Social and administrative infrastructure applies to health care, education, technical assistance to governments, etc. Economic Infrastructure is highways, electricity, irrigation, and other large public investment projects. Program aid is balance of payments support. 
TABLE 2

Regressions Showing the Determinants of Aid, Dependent variable: AID/GNP

(panel data using base sample with four samples of 5 year averages 1971-5, 76-80, 81-85, 86-90)

\begin{tabular}{|c|c|c|c|c|c|}
\hline Variable: & I & II & III & IV & $\mathrm{V}$ \\
\hline & OLS & OLS & OLS & OLS & $\mathrm{FE}$ \\
\hline $\begin{array}{l}\log \text { of relative GNP/capita } \\
\text { at start of period }\end{array}$ & $\begin{array}{l}-0.036 \\
(13.5)\end{array}$ & $\begin{array}{l}-0.033 \\
(10.3)\end{array}$ & $\begin{array}{l}-0.022 \\
(11.3)\end{array}$ & $\begin{array}{l}-0.034 \\
(8.19)\end{array}$ & $\begin{array}{l}-0.035 \\
(4.97)\end{array}$ \\
\hline $\log$ (Population) & $\begin{array}{l}-0.032 \\
(9.37)\end{array}$ & $\begin{array}{l}-0.031 \\
(8.33)\end{array}$ & & $\begin{array}{r}-0.032 \\
(8.82)\end{array}$ & $\begin{array}{r}-0.076 \\
(0.91)\end{array}$ \\
\hline Friends of US & & $\begin{array}{l}0.011 \\
(2.68)\end{array}$ & & $\begin{array}{l}0.008 \\
(1.68)\end{array}$ & $\begin{array}{l}0.017 \\
(4.35)\end{array}$ \\
\hline Friend of OPEC & & $\begin{array}{l}0.020 \\
(3.56)\end{array}$ & & $\begin{array}{l}0.023 \\
(3.82)\end{array}$ & $\begin{array}{l}0.010 \\
(1.67)\end{array}$ \\
\hline Friend of France & & $\begin{array}{l}0.015 \\
(2.09)\end{array}$ & & $\begin{array}{l}0.016 \\
(1.96)\end{array}$ & NA \\
\hline Twice-Lagged Aid/GNP & & & $\begin{array}{l}0.486 \\
(12.1)\end{array}$ & & \\
\hline Per capita GNP growth rate & & $\begin{array}{l}0.053 \\
(1.17)\end{array}$ & & & $\begin{array}{l}0.047 \\
(1.01)\end{array}$ \\
\hline Terms of Trade & & $\begin{array}{l}0.002 \\
(0.05)\end{array}$ & & & $\begin{array}{l}0.028 \\
(0.54)\end{array}$ \\
\hline Debt Rescheduling & & $\begin{array}{l}-0.004 \\
(0.90)\end{array}$ & & & $\begin{array}{r}-0.000 \\
(0.01)\end{array}$ \\
\hline Sub-Saharan Africa & & $\begin{array}{l}0.006 \\
(0.73)\end{array}$ & & & \\
\hline Asia & & $\begin{array}{l}-0.005 \\
(0.67)\end{array}$ & & & \\
\hline Latin America & & $\begin{array}{l}-0.00 \\
(0.11)\end{array}$ & & & \\
\hline Infant Mortality at start of period & & & & $\begin{array}{l}-0.005 \\
(0.73)\end{array}$ & $\begin{array}{l}0.022 \\
(1.67)\end{array}$ \\
\hline Life Expectancy at start of period & & & & $\begin{array}{l}-0.019 \\
(0.59)\end{array}$ & $\begin{array}{l}0.081 \\
(0.95)\end{array}$ \\
\hline Constant & $\begin{array}{l}0.168 \\
(0.02)\end{array}$ & $\begin{array}{l}0.165 \\
(7.04)\end{array}$ & & $\begin{array}{l}0.267 \\
(1.72)\end{array}$ & \\
\hline $\mathrm{R} 2$ & 0.649 & 0.738 & 0.708 & 0.695 & 0.962 \\
\hline SEE & 0.0248 & 0.0216 & 0.0233 & 0.0233 & 0.0174 \\
\hline $\mathrm{N}$ & 309 & 265 & 145 & 307 & 254 \\
\hline
\end{tabular}

Notes: 1. t-statistics in parentheses, OLS and Fixed Effect (FE).

2. The standard errors for the OLS estimates are adjusted for a random individual specific component.

3. Each regression includes three time dummies not reported here. 


\begin{tabular}{|c|c|c|}
\hline \multicolumn{3}{|c|}{$\begin{array}{l}\text { TABLE } 3 \\
\text { Tests for Permanence and Trend of Aid/GNP Ratio } \\
\mathrm{f}=\mathrm{cte}+\mathrm{f} \mathrm{H}_{\mathrm{t}}\end{array}$} \\
\hline Number of countries: & 20 year trend $1971-90$ & 10 year trend $1981-90$ \\
\hline with positive trend & 56 & 57 \\
\hline with negative trend & 35 & 44 \\
\hline \multicolumn{3}{|c|}{$\begin{array}{l}\text { of which aid predicted to be } \\
\text { zero in: }\end{array}$} \\
\hline under 20 years & 19 & 21 \\
\hline 20 - 50 years & 9 & 5 \\
\hline more than 50 years & 7 & 8 \\
\hline
\end{tabular}

Estimates are reported for countries where there was at least 14 years of data available.

The 20 and 10 year trends were statistically significant (5\% level) in 66 countries and 48 countries respectively. The predictions were calculated by extrapolating aid based on the estimate for the trend and taking the initial level of assistance as the average assistance earned in the years 1988-90. 


\section{TABLE 4}

\section{The Impact of Foreign Aid on Macroeconomic Performance, Tax Rates and Human Development Indicators}

\section{(The coefficients on foreign aid/GNP in alternative regressions, dependent variables are shown in the left column)}

\begin{tabular}{|c|c|c|c|c|c|c|c|c|}
\hline Dependent Variable: & $\mathrm{I}$ & II & III & IV & $\mathrm{V}$ & VI & VII & VIII \\
\hline Total Consumption & $\begin{array}{l}1.016 \\
(4.83) \\
\end{array}$ & $\begin{array}{l}1.048 \\
(5.36)\end{array}$ & $\begin{array}{r}1.015 \\
(2.80) \\
\end{array}$ & $\begin{array}{r}1.038 \\
(3.19) \\
\end{array}$ & $\begin{array}{r}0.429 \\
(5.17) \\
\end{array}$ & $\begin{array}{l}1.127 \\
(3.67)\end{array}$ & $\begin{array}{l}1.358 \\
(4.48) \\
\end{array}$ & $\begin{array}{r}0.954 \\
(4.40) \\
\end{array}$ \\
\hline Private Consumption & $\begin{array}{l}0.232 \\
(0.89) \\
\end{array}$ & $\begin{array}{l}0.329 \\
(1.41) \\
\end{array}$ & $\begin{array}{l}0.260 \\
(0.58) \\
\end{array}$ & $\begin{array}{l}0.332 \\
(0.83) \\
\end{array}$ & $\begin{array}{l}0.101 \\
(1.01)\end{array}$ & $\begin{array}{l}0.345 \\
(0.92) \\
\end{array}$ & $\begin{array}{l}0.151 \\
(0.48) \\
\end{array}$ & $\begin{array}{r}0.577 \\
(2.67) \\
\end{array}$ \\
\hline $\begin{array}{l}\text { Public and Private } \\
\text { Investment }\end{array}$ & $\begin{array}{l}0.030 \\
(0.17) \\
\end{array}$ & $\begin{array}{r}0.015 \\
(0.09) \\
\end{array}$ & $\begin{array}{l}0.068 \\
(0.23) \\
\end{array}$ & $\begin{array}{l}0.067 \\
(0.25) \\
\end{array}$ & $\begin{array}{l}0.429 \\
(5.17) \\
\end{array}$ & $\begin{array}{l}0.153 \\
(0.62) \\
\end{array}$ & $\begin{array}{l}0.261 \\
(1.01) \\
\end{array}$ & $\begin{array}{r}0.053 \\
(0.27) \\
\end{array}$ \\
\hline $\begin{array}{l}\text { Government } \\
\text { Consumption }\end{array}$ & $\begin{array}{l}0.784 \\
(6.39) \\
\end{array}$ & $\begin{array}{r}0.719 \\
(5.74) \\
\end{array}$ & $\begin{array}{l}0.755 \\
(3.54) \\
\end{array}$ & $\begin{array}{l}0.707 \\
(3.68) \\
\end{array}$ & $\begin{array}{l}0.327 \\
(6.05) \\
\end{array}$ & $\begin{array}{l}0.782 \\
(4.55) \\
\end{array}$ & $\begin{array}{l}1.207 \\
(5.80) \\
\end{array}$ & $\begin{array}{r}0.377 \\
(3.18) \\
\end{array}$ \\
\hline $\begin{array}{l}\text { Black Market } \\
\text { Premium (\%) }\end{array}$ & $\begin{array}{l}0.029 \\
(0.82) \\
\end{array}$ & $\begin{array}{l}0.009 \\
(0.28) \\
\end{array}$ & $\begin{array}{r}0.001 \\
(0.02) \\
\end{array}$ & $\begin{array}{r}-0.035 \\
(0.59) \\
\end{array}$ & $\begin{array}{l}0.021 \\
(1.32) \\
\end{array}$ & $\begin{array}{l}0.097 \\
(1.84) \\
\end{array}$ & NA & NA \\
\hline Indirect Taxes & $\begin{array}{r}-0.034 \\
(0.22) \\
\end{array}$ & $\begin{array}{r}-0.115 \\
(0.79) \\
\end{array}$ & $\begin{array}{r}-0.007 \\
(0.03) \\
\end{array}$ & $\begin{array}{r}-0.045 \\
(0.18) \\
\end{array}$ & $\begin{array}{r}-0.004 \\
(0.07) \\
\end{array}$ & $\begin{array}{l}0.092 \\
(0.38) \\
\end{array}$ & $\begin{array}{r}-0.384 \\
(1.58) \\
\end{array}$ & $\begin{array}{r}0.171 \\
(1.27) \\
\end{array}$ \\
\hline Inflation Tax & $\begin{array}{l}0.395 \\
(0.15) \\
\end{array}$ & $\begin{array}{r}-0.256 \\
(0.11) \\
\end{array}$ & $\begin{array}{r}-6.986 \\
(1.52) \\
\end{array}$ & $\begin{array}{r}-7.633 \\
(1.83) \\
\end{array}$ & $\begin{array}{l}0.095 \\
(0.10) \\
\end{array}$ & $\begin{array}{l}2.298 \\
(0.61) \\
\end{array}$ & $\begin{array}{l}0.086 \\
(0.01) \\
\end{array}$ & $\begin{array}{r}24.42 \\
(1.76) \\
\end{array}$ \\
\hline $\begin{array}{l}\text { Change in Log Infant } \\
\text { Mortality }\end{array}$ & $\begin{array}{l}-0.202 \\
(0.42) \\
\end{array}$ & $\begin{array}{r}-0.107 \\
(0.24) \\
\end{array}$ & $\begin{array}{r}-0.264 \\
(0.30) \\
\end{array}$ & $\begin{array}{r}-0.356 \\
(0.45) \\
\end{array}$ & $\begin{array}{r}-0.242 \\
(1.35) \\
\end{array}$ & $\begin{array}{r}-0.888 \\
(1.24) \\
\end{array}$ & $\begin{array}{l}0.061 \\
(0.14) \\
\end{array}$ & $\begin{array}{r}0.165 \\
(0.61) \\
\end{array}$ \\
\hline $\begin{array}{l}\text { Change in Life } \\
\text { Expectancy }\end{array}$ & $\begin{array}{l}-0.024 \\
(0.29) \\
\end{array}$ & $\begin{array}{r}-0.006 \\
(0.08) \\
\end{array}$ & $\begin{array}{l}0.066 \\
(0.47) \\
\end{array}$ & $\begin{array}{l}0.061 \\
(0.47) \\
\end{array}$ & $\begin{array}{l}0.020 \\
(0.58) \\
\end{array}$ & $\begin{array}{l}0.186 \\
(1.71) \\
\end{array}$ & $\begin{array}{l}0.035 \\
(0.20) \\
\end{array}$ & $\begin{array}{r}0.079 \\
(1.38) \\
\end{array}$ \\
\hline $\begin{array}{l}\text { Change in Log Primary } \\
\text { Schooling }\end{array}$ & $\begin{array}{l}-0.688 \\
(1.30)\end{array}$ & $\begin{array}{r}-1.144 \\
(1.94)\end{array}$ & $\begin{array}{l}-1.52 \\
(1.46)\end{array}$ & $\begin{array}{r}-0.993 \\
(1.11)\end{array}$ & $\begin{array}{l}-0.148 \\
(0.68)\end{array}$ & $\begin{array}{r}-0.663 \\
(0.89)\end{array}$ & NA & NA \\
\hline
\end{tabular}

Regressions are as follows:

I. OLS with t-statistics adjusted for country specific random effect, ten year averaged data with RHS variables as in Table 5.

II. OLS with t-statistics adjusted for country specific random effect, ten year averaged data with RHS variables: LGNPCAP, regional dummies for Sub-Saharan Africa, Asia and Latin America, and one time dummy.

III. IV estimates, ten year averaged data, with regressors as in I, and log of population as an instrument for AID.

IV. IV estimates, ten year averaged data, with regressors as in I, and political proxies "friends of US", "friends of OPEC", "friends of France" and log of population as instruments for aid.

V. IV estimates, ten year averaged data, in the FULL SAMPLE including countries with aid/GNP ratios greater than 0.15 . Regressors as in I above.

VI. IV estimates, ten year averaged data, including only those observations with aid/GNP ratios less than 0.10 . Regressors as in I above.

VII. IV estimates, five year averaged data, in the BASE sample with regressors as in I and twice-lagged aid as an instrument.

VIII. Fixed effects estimator, BASE sample, with regressors as in I. 
TABLE 5

Regressions Showing the Impact of Aid on Consumption,

Investment, Taxes and Infant Mortality

(panel data using base sample with decade-averaged data 1971-80,81-90)

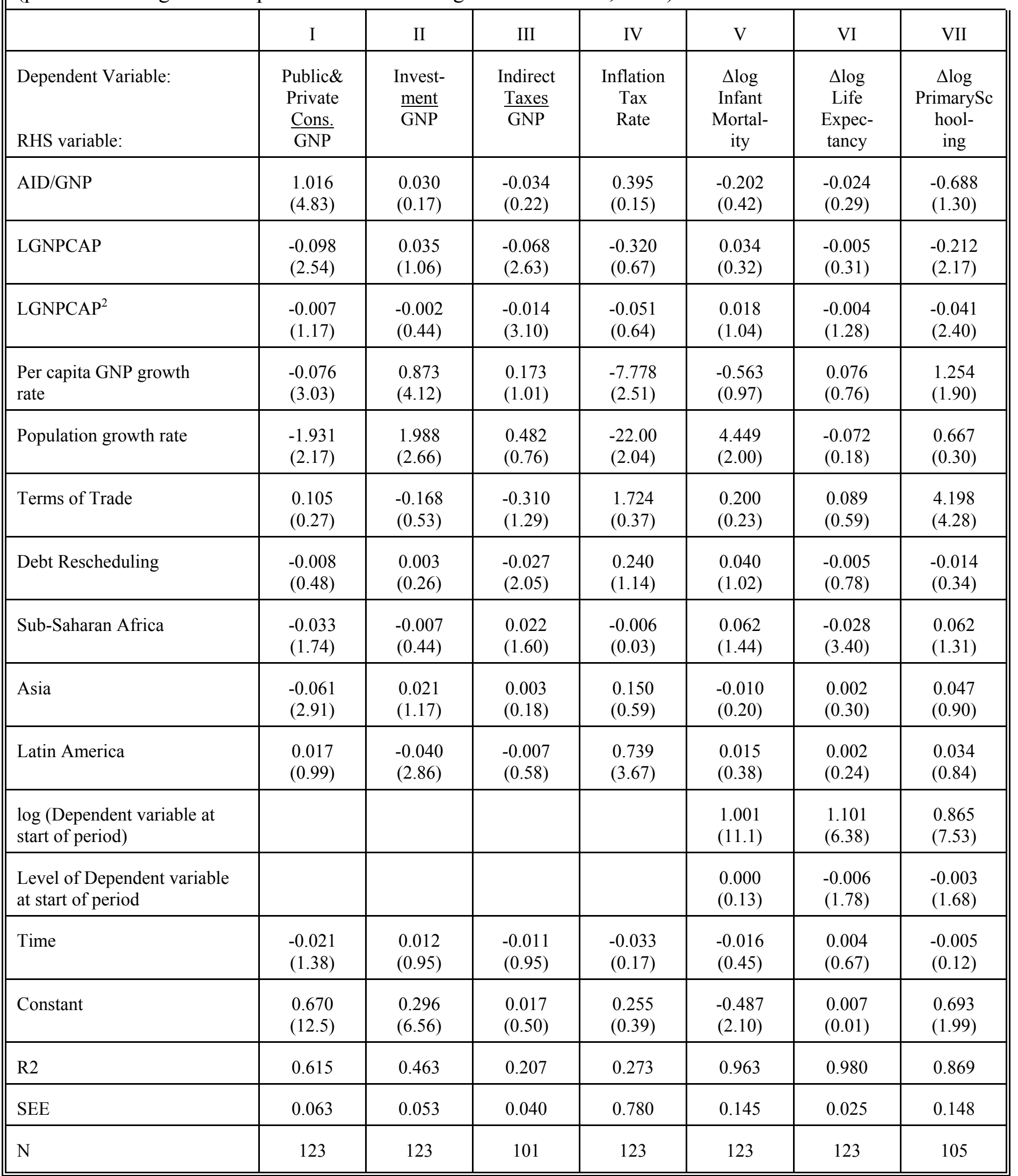


Notes: 1. Ols estimates, $t$-statistics in parentheses, standard errors are adjusted for a random individual specific component. 
TABLE 6

t-Statistics from Robustness Tests for Each Donors Aid

(test of the null hypothesis that each donor's aid has the same impact as aid from other donors)

\begin{tabular}{||l|c|c|c|c|c|c||}
\hline & $\begin{array}{l}\text { Multi- } \\
\text { lateral }\end{array}$ & $\begin{array}{c}\text { United } \\
\text { States }\end{array}$ & OPEC & France & Japan & $\begin{array}{c}\text { United } \\
\text { Kingdo } \\
\text { m }\end{array}$ \\
\hline Total Consumption & 0.15 & -0.34 & $1.69^{*}$ & 0.17 & -0.39 & -0.36 \\
\hline Private Consumption & $1.77^{*}$ & 0.21 & 0.54 & 0.54 & 0.67 & -0.83 \\
\hline Investment & -1.09 & 0.32 & $-1.74^{*}$ & 1.01 & -1.09 & 0.60 \\
\hline Public Consumption & - & -1.04 & $1.74^{*}$ & -0.87 & $-2.12^{* *}$ & 1.14 \\
\hline Black Market Premium & -0.92 & -0.86 & 0.46 & -1.64 & -1.07 & 0.66 \\
\hline Indirect Taxes & 1.26 & -1.21 & -0.40 & 0.01 & -0.92 & 1.42 \\
\hline Inflation Tax & -0.21 & $-2.76^{* * *}$ & 0.52 & -0.65 & -1.08 & 0.71 \\
\hline$\Delta \log ($ Infant Mortality) & -0.64 & 0.06 & -0.01 & -0.24 & -0.22 & 0.53 \\
\hline$\Delta \log$ (Life Expectancy) & -0.47 & $2.99^{* * *}$ & -0.30 & -0.83 & -0.48 & 0.62 \\
\hline$\Delta \log$ (Primary Schooling) & -1.90 & 0.62 & -1.21 & -1.07 & 0.68 & 1.22 \\
\hline \hline
\end{tabular}

Notes to Table:

${ }^{* * *}:$ significant at $1 \%$ level

${ }^{* *}$ : significant at 5\% level

* : significant at $10 \%$ level 
TABLE 7

The Impact of Foreign Aid Allowing for Differences in Political Regimes and Political Liberties

(The table reports the coefficient on the political regime variable and political regime interacted with Foreign Aid/GNP in alternative regression equations)

\begin{tabular}{|c|c|c|c|c|}
\hline \multirow[t]{2}{*}{$\begin{array}{l}\text { Measure of the Political } \\
\text { Regime: }\end{array}$} & \multicolumn{2}{|c|}{$\begin{array}{l}\text { Index of Political Liberties } \\
\text { (dummy variable from .14 to } 1 \text { ) }\end{array}$} & \multicolumn{2}{|c|}{$\begin{array}{c}\text { Liberal Democracies } \\
\text { (dummy }=1 \text { if democratic) }\end{array}$} \\
\hline & Own effect & $\begin{array}{l}\text { Interaction } \\
\text { with Foreign } \\
\text { Aid/GNP }\end{array}$ & Own Effect & $\begin{array}{c}\text { Interaction } \\
\text { with Foreign } \\
\text { Aid/GNP }\end{array}$ \\
\hline Dependent Variable: & I & II & III & IV \\
\hline Total Consumption & $\begin{array}{l}0.038 \\
(0.99) \\
\end{array}$ & $\begin{array}{l}0.583 \\
(0.81) \\
\end{array}$ & $\begin{array}{l}0.003 \\
(0.14)\end{array}$ & $\begin{array}{l}0.253 \\
(0.62)\end{array}$ \\
\hline Private Consumption & $\begin{array}{l}0.044 \\
(0.94)\end{array}$ & $\begin{array}{l}0.771 \\
(0.87)\end{array}$ & $\begin{array}{l}0.008 \\
(0.33)\end{array}$ & $\begin{array}{l}0.303 \\
(0.60)\end{array}$ \\
\hline $\begin{array}{l}\text { Public and Private } \\
\text { Investment }\end{array}$ & $\begin{array}{l}-0.046 \\
(1.42)\end{array}$ & $\begin{array}{l}-0.055 \\
(0.09) \\
\end{array}$ & $\begin{array}{r}-0.010 \\
(0.57) \\
\end{array}$ & $\begin{array}{l}0.059 \\
(0.17) \\
\end{array}$ \\
\hline $\begin{array}{l}\text { Government } \\
\text { Consumption }\end{array}$ & $\begin{array}{l}-0.006 \\
(0.27)\end{array}$ & $\begin{array}{l}-0.188 \\
(0.44)\end{array}$ & $\begin{array}{l}-0.005 \\
(0.45)\end{array}$ & $\begin{array}{l}-0.051 \\
(0.21)\end{array}$ \\
\hline $\begin{array}{l}\text { Black Market } \\
\text { Premium }\end{array}$ & $\begin{array}{l}-0.006 \\
(0.87)\end{array}$ & $\begin{array}{l}0.045 \\
(0.38)\end{array}$ & $\begin{array}{l}0.014 \\
(0.04)\end{array}$ & $\begin{array}{l}-0.036 \\
(0.54)\end{array}$ \\
\hline Indirect Taxes & $\begin{array}{l}-0.009 \\
(0.35) \\
\end{array}$ & $\begin{array}{l}-0.022 \\
(0.04) \\
\end{array}$ & $\begin{array}{l}-0.009 \\
(0.65)\end{array}$ & $\begin{array}{l}0.088 \\
(0.31) \\
\end{array}$ \\
\hline Inflation Tax & $\begin{array}{l}-0.135 \\
(0.28)\end{array}$ & $\begin{array}{l}-3.450 \\
(0.386)\end{array}$ & $\begin{array}{l}-0.322 \\
(1.29)\end{array}$ & $\begin{array}{l}0.874 \\
(0.18)\end{array}$ \\
\hline $\begin{array}{l}\text { Change in Log Infant } \\
\text { Mortality }\end{array}$ & $\begin{array}{l}-0.154 \\
(1.74) \\
\end{array}$ & $\begin{array}{l}1.782 \\
(1.08) \\
\end{array}$ & $\begin{array}{l}-0.066 \\
(1.41) \\
\end{array}$ & $\begin{array}{l}0.0735 \\
(0.77) \\
\end{array}$ \\
\hline $\begin{array}{l}\text { Change in Log Life } \\
\text { Expectancy }\end{array}$ & $\begin{array}{l}0.010 \\
(0.62) \\
\end{array}$ & $\begin{array}{l}0.030 \\
(0.10) \\
\end{array}$ & $\begin{array}{l}0.006 \\
(0.79) \\
\end{array}$ & $\begin{array}{l}0.075 \\
(0.44) \\
\end{array}$ \\
\hline $\begin{array}{l}\text { Change in Log Primary } \\
\text { Schooling }\end{array}$ & $\begin{array}{l}-0.044 \\
(0.44)\end{array}$ & $\begin{array}{l}1.209 \\
(0.64)\end{array}$ & $\begin{array}{r}-0.036 \\
(0.68)\end{array}$ & $\begin{array}{l}1.121 \\
(0.88)\end{array}$ \\
\hline
\end{tabular}

Notes to table: 1. specific random effect.

2. Each regression has right hand side variables as in Table 5 plus the political regime proxy and an interaction term formed by multiplying the political regime proxy by the aid/GNP ratio. 
TABLE 8

Regressions Showing the Relation Between Political Regimes and Infant Mortality

Dependent variable: Log (Infant Mortality)

(panel data using decade averaged data 1971-80,81-90)

\begin{tabular}{|c|c|c|c|c|c|}
\hline Variable: & ALL & ALL & $\begin{array}{c}\text { Exc Sub-Saharan } \\
\text { Africa }\end{array}$ & $\begin{array}{l}\text { Exc } \\
\text { Asia }\end{array}$ & $\begin{array}{l}\text { Exc Latin } \\
\text { America }\end{array}$ \\
\hline & I & II & III & IV & $\mathrm{V}$ \\
\hline Political Rights Indicator & & $\begin{array}{l}-0.343 \\
(3.06)\end{array}$ & $\begin{array}{l}-0.378 \\
(2.69)\end{array}$ & $\begin{array}{l}-0.409 \\
(3.62)\end{array}$ & $\begin{array}{l}-0.283 \\
(2.11)\end{array}$ \\
\hline Democratic Regime & $\begin{array}{l}-0.328 \\
(4.62)\end{array}$ & & & & \\
\hline Socialist Regime & $\begin{array}{l}-0.203 \\
(2.40)\end{array}$ & & & & \\
\hline Military Authoritarian and Other & $\begin{array}{l}-0.146 \\
(1.88)\end{array}$ & & & & \\
\hline LGNPCAP & $\begin{array}{l}-0.556 \\
(3.53) \\
\end{array}$ & $\begin{array}{l}-0.676 \\
(4.23) \\
\end{array}$ & $\begin{array}{l}-0.616 \\
(2.82) \\
\end{array}$ & $\begin{array}{l}-0.567 \\
(2.96) \\
\end{array}$ & $\begin{array}{r}-0.694 \\
(4.18) \\
\end{array}$ \\
\hline LGNPCAP" & $\begin{array}{l}-0.020 \\
(0.96)\end{array}$ & $\begin{array}{l}-0.041 \\
(1.62)\end{array}$ & $\begin{array}{l}-0.026 \\
(0.69)\end{array}$ & $\begin{array}{r}-0.030 \\
(1.01)\end{array}$ & $\begin{array}{r}-0.044 \\
(1.68)\end{array}$ \\
\hline Per capita GNP growth rate & $\begin{array}{l}-2.996 \\
(3.17) \\
\end{array}$ & $\begin{array}{l}-3.665 \\
(3.76) \\
\end{array}$ & $\begin{array}{l}-3.725 \\
(2.72) \\
\end{array}$ & $\begin{array}{r}-3.637 \\
(3.45) \\
\end{array}$ & $\begin{array}{r}-3.509 \\
(3.44) \\
\end{array}$ \\
\hline Population growth rate & $\begin{array}{l}24.45 \\
(6.79)\end{array}$ & $\begin{array}{l}22.97 \\
(6.14)\end{array}$ & $\begin{array}{l}24.57 \\
(5.11)\end{array}$ & $\begin{array}{l}22.79 \\
(5.92)\end{array}$ & $\begin{array}{l}26.70 \\
(6.12)\end{array}$ \\
\hline Sub-Saharan Africa & $\begin{array}{l}0.048 \\
(0.56)\end{array}$ & $\begin{array}{l}-0.052 \\
(0.64)\end{array}$ & NA & $\begin{array}{r}-0.017 \\
(0.20)\end{array}$ & $\begin{array}{r}-0.079 \\
(0.98)\end{array}$ \\
\hline Asia & $\begin{array}{l}-0.327 \\
(4.07) \\
\end{array}$ & $\begin{array}{l}-0.355 \\
(4.32) \\
\end{array}$ & $\begin{array}{l}-0.386 \\
(4.19) \\
\end{array}$ & NA & $\begin{array}{r}-0.362 \\
(4.48) \\
\end{array}$ \\
\hline Latin America & $\begin{array}{l}-0.198 \\
(2.66)\end{array}$ & $\begin{array}{l}-0.151 \\
(2.00)\end{array}$ & $\begin{array}{l}-0.153 \\
(1.85)\end{array}$ & $\begin{array}{l}-0.149 \\
(2.02)\end{array}$ & NA \\
\hline $\begin{array}{l}\text { Time } \\
(1971-1980=1)\end{array}$ & $\begin{array}{l}0.201 \\
(3.95)\end{array}$ & $\begin{array}{l}0.200 \\
(3.76)\end{array}$ & $\begin{array}{l}0.213 \\
(7.43)\end{array}$ & $\begin{array}{l}0.242 \\
(4.21)\end{array}$ & $\begin{array}{l}0.184 \\
(3.30)\end{array}$ \\
\hline Constant & $\begin{array}{c}2.35 \\
(10.3) \\
\end{array}$ & $\begin{array}{c}2.20 \\
(9.40) \\
\end{array}$ & $\begin{array}{c}2.22 \\
(7.43) \\
\end{array}$ & $\begin{array}{c}2.40 \\
(8.64)\end{array}$ & $\begin{array}{c}2.08 \\
(8.63) \\
\end{array}$ \\
\hline R2 & 0.827 & 0.813 & 0.764 & 0.813 & 0.838 \\
\hline
\end{tabular}




\begin{tabular}{||l|c|c|c|c|c||}
\hline SEE & 0.294 & 0.303 & 0.329 & 0.291 & 0.294 \\
\hline $\mathrm{N}$ & 151 & 151 & 92 & 125 & 119 \\
\hline
\end{tabular}

Notes: 1. t-statistics in parentheses, standard errors are adjusted for a country specific random component.

FIGURE 1

\author{
Average Aid/GNP and Average Per Capita Growth \\ (Base Sample, 1971-1990)
}




\section{FIGURE 2A}

Optimal Distortions under Alternative Political Regimes

\section{FIGURE 2B}

The Impact of Aid on Distortions under Alternative Political Regimes 


\section{FIGURE 3}

Nations's Relative Incomes and Political Represenativeness 


\section{FIGURE 4}

CPR Plot of the Improvement in Infant Mortality and Aid/GNP Ratios using the Base Sample of Countries

(20 year averaged data: 1971-90) 


\section{REFERENCES}

Barro, Robert J., (1994), 'Growth and Democracy', mimeo, Harvard University.

Barro, Robert J., (1990), 'Government Spending in a Simple Model of Endogenous Growth', Journal of Political Economy, Vol.98(5) pp.103-26.

Bauer, P.T., (1971), Dissent on Development, Weidenfield and Nicholson: London, 1971.

Bayart, Jean-Francois, (1992), The State in Africa: The Politics of the Belly, Longman: New York.

Becker, Gary S., (1983), 'A Theory of Competition among Pressure Groups for Political Influence', Quarterly Journal of Economics, Vol.98(3), August, pp.371-400.

Becker, Gary S., (1985a), 'Pressure Groups and Political Behavior' in Richard D. Coe and Charles K. Wilber, (eds), Capitalism and Democracy: Schumpeter Revisited, University of Notre Dame Press: Notre Dame, pp.120-146.

Becker, Gary S., (1985b), 'Public Policies, Pressure Groups, and Dead Weight Costs", Journal of Public Economics, Vol.28(3), December, pp.329-347.

Becker, Gary S., (1989), 'Political Competition among Interest Groups', in Jason F. Shogren, (ed), The Political Economy of Government Regulation, Kluwer Academic: Dordrecht and London, pp.13-27.

Caldwell, John C., (1986), 'Routes to Low Mortality in Poor Countries', Population and Development Review, 12(2), pp.171-212. 
Casella, Alessandra and Barry Eichengreen, (1994), 'Can Foreign Aid Accelerate Stabilization', National Bureau of Economic Research Working Paper No. 4694.

Chenery, Hollis and Peter Eckstein, (1970), 'Development Alternatives for Latin America', Journal of Political Economy, Vol.78(4), pp.966-1006.

Chenery, Hollis B. and Moises Syrquin, (1975), Patterns of Development: 1950-1970, Oxford University Press: Oxford.

Congleton, Roger D., (1991), 'Ideological Conviction and Persuasion in the Rent-Seeking Society', Journal of Public Economics, Vol.44(1), pp.65-86.

Conteh-Morgan, Earl., (1990), American Foreign Aid and Global Power Projection: The Geopolitics of Resource Allocatio, Dartmouth: England.

Derbyshire, J. Denis and Ian Derbyshire, (1989), Political Systems of the World, W\&R Chambers: Edinburgh.

Dreze, Jean and Amartya Sen, (1992), Hunger and Public Action, Oxford University Press: Oxford.

Flegg, A.T., (1982),'Inequality of Income, Illiteracy and Medical Care as Determinants of Infant Mortality in Underdeveloped Countries', Population Studies, Vol.36(3), pp.441-458.

Friedman, Milton, (1958), 'Foreign Economic Aid', Yale Review Vol.47(4), pp.500-516.

Gastil, Raymond D., Freedom in the World: Political Rights and Civil Liberties 1988-1989, Freedom House: New York. 
Griffin, Keith, (1970), 'Foreign Capital, Domestic Savings and Economic Development', Oxford Bulletin of Economics and Statistics, Vol.32, February, pp.99-112.

Khilji, Nasir M and Ernest M Zampelli, (1991), 'The Fungibility of US Assistance to Developing Countries and the Impact on Recipient Expenditures: A Case Study of Pakistan', World Development, 19(8),pp.1095-105.

Krieger, Joel (ed), (1993), The Oxford Companion to Politics of the World, Oxford University Press: NewYork, Oxford, p.1056.

Levy, Victor, (1987), 'Anticipated Development Assistance and Temporary Relief Aid', Quarterly Journal of Economics, Vol.97, pp.446-58.

Levy, Victor, (1988), 'Aid and Growth in Sub-Saharan Africa: The Recent Experience', European Economic Review, Vol.32(9), pp.1777-95.

Lucas, Robert E., Jr. (1988), 'On the Mechanics of Economic Development', Journal of Monetary Economics, Vol.22(1), pp.3-42.

Lucas, Robert E., Jr. (1990), 'Why Doesn't Capital Flow from Rich to Poor Countries?', American Economic Review, Vol.80(2), pp.92-96.

Maizels, Alfred and Machiko K. Nissanke, (1984), 'Motivations for Aid to Developing Countries', World Development, Vol.12(9), pp.879-900.

Mankiw, N. Gregory, (1987), 'The Optimal Collection of Seigniorage: Theory and Evidence', Journal of Monetary Economics, Vol.20(2), pp.327-341. 
Mankiw, N. Gregory, David Romer, and David N Weil, (1992), 'A Contribution to the Empirics of Economic Growth', Quarterly Journal of Economics, Vol.107(2), pp.407-37.

McKinlay, R. D. and R. Little, (1977), 'A Foreign Policy Model of US Bilateral Aid Allocation', World Politics, Vol.30(1), pp.58-86.

McKinlay, R.D. and R. Little, (1978a), 'A Foreign Policy Model of the Distribution of British Bilateral Aid: 1960-70', British Journal of Political Science, Vol.8, pp.313-322.

McKinlay, R.D. and R. Little, (1978b), 'The French Aid Relationship: A Foreign Policy Model of the Distribution of French Bilateral Aid: 1964-1970', Development and Change, Vol. 9, pp.459-478.

McKinlay, R.D. and R. Little, (1979), 'The US Aid Relationship: A test of the Recipient Need and Donor Interest Models', Political Studies, Vol.27(2), pp.236-250.

Mosley, Paul, John Huson, and Sara Horrell, (1987), 'Aid, the Public Sector and the Market in Less Developed Countries', Economic Journal, Vol.97, September, pp.616-641.

Mosley, Paul, Jane Harrigan and John Toye, (1991), Aid and Power: The World Bank and Policy Based Lending, Volume 1, Routledge Press: London, pp.317.

Mueller, Dennis C., (1989), Public Choice II, Cambridge University Press: Cambridge.

Murphy, Kevin M, Andrei Shleifer, and Robert W Vishny, (1993), 'Why Is Rent-Seeking So Costly to Growth?', American Economic Review, Vol.83(2), pp.409-414. 
Olson, Mancur, (1993), 'Dictatorship, Democracy, and Development', American Political Science Review, Vol.87(3), September, pp.56776.

Organization for Economic Cooperation and Development, (1992), Development Cooperation Report, OECD: Paris.

Pack, Howard and Janet Rothenberg Pack, (1990), 'Is Foreign Aid Fungible? The Case of Indonesia', Economic Journal, Vol.100 (399), pp.188-94.

Pack, Howard and Janet Rothenberg Pack (1993), 'Foreign Aid and the Question of Fungibility', Review of Economics and Statistics, Vol.75(2), pp.258-65.

Papanek, G.F., (1972), 'The Effect of Aid and other Resource Transfers on Savings and Growth in Less Developed Countries', Economic Journal, Vol.82(327), pp.934 951.

Papanek, Gustav F., (1973), 'Aid, Foreign Private Investment, Savings and Growth in Less Developed Countries', Journal of Political Economy 81(1), pp.121-130.

Persson, Torsten and Guido Tabellini. (1994), 'Is Inequality Harmful for Growth." American Economic Review, Vol.84(3), pp.600-622.

Quah, Danny, (1993), 'Galton's Fallacy and Tests of the Convergence Hypothesis', Scandinavian Journal of Economics, Vol.95(4), pp.427-443.

Romer, Paul M., (1986), 'Increasing Returns and Long-run Growth." Journal of Political Economy, Vol.94(5), pp.1002-37.

Rostow, Walt Whitman, (1990), The Stages Of Economic Growth: A Non-communist Manifesto, third ed, Cambridge University Press: New York and Melbourne. 
Sachs, Jeffrey, 'Russia's Struggle with Stabilization: Conceptual Issues and Evidence', paper presented at the Annual Bank Conference on Development Economics, World Bank, Washington DC 1994.

Sahn, David E., ed, (1994), Adjusting to Policy Failure in African Economies, Cornell University Press: Ithaca.

Tullock, Gordon, (1987), Autocracy, Lancaster and Dordrecht; Kluwer Academic: Hingham, Mass, pages xii, 231.

Weisskopf, Thomas E., (1972), 'The Impact of Foreign Capital Inflow on Domestic Savings in Underdeveloped Countries', Journal of international Economics, pp.25-38.

Zimmerman, David J., (1992), 'Regression toward Mediocrity in Economic Stature', American Economic Review, Vol.82(3), pp.409-29.

1. Sundrum (1992) page 74.

2. These authors go much further. Both argue that poverty reflects harmful political regimes that introduce distortionary policies for the benefits of a narrow political elite. Foreign aid can actually cause a poverty trap if it strengthens these governments so they can stay in power.

3. Bayart (1992) page 88.

4. Krieger (1992) page 730.

5. As shown in Table 1, three quarters of foreign aid is provided by bilateral donors and this rarely has policy conditionality attached. IMF loans and World Bank loans are sometimes conditional on major policy changes but the effectiveness of these restrictions is questionable. This is particularly true over the sample period of my empirical work. See eg Mosley et al (1991), Khan (1986). 
6. This can be interpreted as an assumption about the separability of decision making. If aid is given for political and strategic reasons, then the recipient's choice of transfers, spending and tax policies may not be affected by any agreements that are reached over reciprocal political and strategic support.

7. In reality there are many tax and expenditures that governments do target. There is a well known bias for many governments to provide relatively expensive health care services, tertiary education, etc, before meeting basic need for literacy and primary health services. Likewise taxes can be waived or reduced for particular groups. My assumption effectively restricts the range of public goods and taxes which this problem would capture. Since most distortionary tax policies have substantial spillover effects in general equilibrium, or they cannot be easily targeted to particular individuals, I believe such policies are bound to spillover into macroeconomic distortions at the national level. Likewise many public services such as roads, defense, and the benefits of sanitation cannot be targeted to particular groups.

8. I also rule out expropriation beyond choice of an income tax.

9. Since each individual in the political elite is identical, this is just the $\left(1-\mathrm{s}^{*}\right) 1_{\mathrm{s}}$

10. Some people argue that aid promotes other capital inflows. If this is true then consumption and investment would rise by more than one dollar for each dollar of aid, and the sum of the coefficients on aid in equations (16) and (17) would be less than one.

11. See Caldwell (1986), Dreze and Sen (1982) and Flegg (1982) for evidence on the determinants of infant mortality, and the past success of government programs to improve health care and reduce infant mortality. The main reason I express (18) in differences rather than levels is that at the start of the 1970s there was no correlation between aid flows and health indicators - in order to determine whether higher aid receipts lead to improvements in these indicators I have to examine changes over time. 
12. Pack and Pack (1993) and Khilji and Zampelli (1991) found that governments were able to, ex-post, fully redirect expenditures agreed to under aid programs to alternative uses. Pack and Pack (1990) found that aid flows were not fungible in Indonesia, and they concluded that this was due to the large amounts concerned.

13. Guyana's current account deficit averaged $41 \%$ of GDP between 1981 and 1990. This was seven standard deviations from the mean for all countries in the base sample. Gabon's average propensity to consume was 0.48 between 1971-80, which was four standard deviations from the mean. This is due to an investment boom between 1974 and 1977 when investment is recorded at two thirds of GNP, but investment falls sharply to $30 \%$ of GDP in 1978. Real consumption falls by $50 \%$ from 1976 to 1978 (measured against 1978) which seems unreasonable given generally smooth patterns of consumption in theory and empirical data. Finally, infant mortality is recorded during some years at more than 1000 per 1000 in Lesotho.

14. The one exception to this is Trumbull and Wall (1994). They present results using fixed effects estimators showing that aid is transferred to countries with high infant mortality indexes and high indexes of civil liberties. I do not find results similar to theirs. I suspect this is because they use annual data from 1986 to 1991 only. The infant mortality indexes reported by the World Bank are based on infrequent surveys (varying but in the range of every five years). They must extrapolate between survey dates. Using fixed effects in short time intervals I suspect Trumbull and Wall may have substantial measurement problems since the within variance would be driven by extrapolations from the last survey. They find similar results to mine and the other authors listed above in OLS regressions.

15. It is possible that the correlation between population and the aid/GNP ratio is spurious. This could occur because I am dividing aid by population and income per capita in order to get the aid/GNP ratio, and then regressing this ratio on population. Since population enters the 
denominator of the left hand side variable and is also an independent variable, I risk creating a spurious correlation. To be sure that this was not driving the negative correlation I also ran a regression of the $\log$ of aid on the log of population, log of GNP per capita and time dummies. The coefficient on population was .052 and significant at the $1 \%$ level in the full sample. Using sample averages of the data, this implies a $1 \%$ rise in population reduces the aid/GNP ratio by .035 . This is similar to the findings reported in Table 2, and hence verifies that the correlation between the aid/GNP ratio and population is not spurious.

16. For example, if a temporary burst in government spending raises the relative price of non-tradable goods, then the aid/GNP ratio will fall since foreign currency aid receipts are unlikely to be correlated with temporary government spending. When the economy returns to sustainable levels of government spending, the aid/GNP ratio will rise. If such government spending also induces temporary increases in output, then a fiscal driven business cycle will cause a negative correlation between current aid and growth, but a positive correlation between lagged aid and growth.

17. Table 4 column 2 shows the results are similar when I exclude all control variables except income per capita. This provides a check against possible bias due to endogeneity of some of the right hand side variables. As an alternative I could have reported (qualitatively similar) results where I instrument the potentially endogenous variables with lagged variables, but this would have been at the cost of one set of observations.

18. The countries are Botswana, Burundi, Cape Verde Island, Central African Republic, Gambia, Guinea-Bisseau, Malawi, Mali, Mauritania (2 observations), Papau New Guinea, Solomon Islands, Somalia and Tanzania.

19. In this dataset the impact of aid on investment is insignificant once I exclude those countries that receive more than $15 \%$ of GNP. I can't determine whether this is due to a country size effect or the level of aid 
receipts since both are highly correlated in my sample.

20. This is an important difference between my findings and previous research which has not explicitly taken into account aid fungibility. For example Levy (1987) finds that the propensity to invest from anticipated aid is higher than the propensity to invest from unanticipated aid, but since he used commitments to construct anticipated aid flows, I suspect he is capturing aid committed to infrastructure and other investment projects that are planned several years in advance. In OLS regressions using actual aid flows he finds the marginal propensity to consume from aid is 0.73 . But Levy $(1987,1988)$ and many of the early papers including Griffin (1972) did not attempt to instrument foreign aid, so it was unclear whether their results were biased. Mosley et al (1987) provide a careful discussion of the importance of instruments when they examine the relation between aid and growth.

21. In the regressions excluding these countries the coefficient on total consumption was 0.93 (t-statistic 4.17) and investment was 0.05 (tstatistic 0.27).

22. It is possible that aid channeled through the government could be used differently than aid distributed through the private sector. To test whether aid not channeled through the government was used differently, I divided the data into two subsamples of high and low spending governments. Low spending governments are observations where the government spending ratio was less than the median. In this subsample the coefficient on private consumption rose to 1.02 (t-statistic 2.52) while the coefficient on government consumption fell to 0.08 (t-statistic 0.71 ). The respective coefficients for high spending governments were 0.18 (t-statistic 0.47) and 0.52 (t-statistic 2.9). In each case the coefficient on investment was insignificant and small, while the coefficient on total consumption was insignificantly different from one.

23. Sundrum (1992) page 74, Table 4.1, line 2.

24. A regression of infant mortality on income predicts that a $10 \%$ rise in GNP causes a 5\% decline in infant mortality. 
25. See Caldwell (1986) and Dreze and Sen (1982) for discussions of the past success of government programs to improve health care and reduce infant mortality. The World Bank (1993) estimates that low income countries would need to spend $3.1 \%$ of GNP to lower infant mortality and raise life expectancy to near western levels. This can be achieved through increased public health facilities, better sanitation, improved literacy (especially maternal literacy), and nationwide vaccination programs. Since these costs are well within average aid receipts of my sample of countries, and well within their own fiscal constraints, failure to achieve better human development conditions must be attributed largely to government failure.

26. These results do not change if I interact political variables with all right hand side variables. For example, using the Derbyshire and Derbyshire index, the coefficients on the interaction terms with foreign aid in these regressions were: total consumption (.015), investment (.213) and on infant mortality (.67). The t-statistics were 0.0, 0.4, and 1.1 respectively.

27. Barro (1994) forecasts democratization of countries. He runs regressions of political liberties on life expectancy (and other RHS variables) and finds a positive correlation. He interprets this positive correlation as evidence that households demand liberties as their standard of living increases, ie democracy is a luxury good. Since I'm controlling for standard of living as measured by income, I suspect this correlation is at least in part driven by a higher propensity for democratic governments to redistribute. This matches theory and empirical evidence in Persson and Tabellini (1994). 